\title{
Richard Neutra's Search for the Southland: California, Latin America and Spain
}

\author{
by BRETT TIPPEY
}

A self-proclaimed 'citizen of the planet', Richard Neutra (1892-1970) was an enthusiastic student of the local cultures and traditions that he had visited during his international travels. ${ }^{1}$ The Ukrainian architect Gregori Warchavchik (1896-1972), whose emigration to Brazil in 1923 paralleled Neutra's to California, noted that even before Neutra arrived in the United States he had already cultivated a deep respect for the architecture and history of world cultures:

Asia, Africa, Europe, Central and South America are familiar to him, [and] global circumstances are close to his heart. Travel, study, and work in many places have unusually widened his horizon. ${ }^{2}$

Like other architects of his generation, the first source beyond his own AustroHungarian tradition to have inspired Neutra early on came from the ancient cultures of the Mediterranean region. During a 1912 tour of the Adriatic coast, the architecture of Renaissance Italy in general, and of Michelangelo and Palladio in particular, sparked in the young Neutra a 'general enthusiasm for the treasures of Italy' ${ }^{3}$ Later, during his tour of duty as a reserve lieutenant in the Austro-Hungarian Imperial Army (1914-18), in which he was stationed on the eastern shores of the Adriatic Sea, Neutra recorded the region's historic Ottoman architecture in his early sketch diaries. ${ }^{4}$

Like his mentor Frank Lloyd Wright (1867-1959), Neutra also became keenly interested in Japanese design, which he had begun to explore long before he visited Japan for the first time in $1930 .{ }^{5}$ This fact is clearly demonstrated in the letters exchanged in the early 1920s between Neutra, then still living in central Europe, and Rudolph Schindler (1887-1953), who had already emigrated to the United States. ${ }^{6}$ Neutra sustained this interest in Japanese culture throughout his career; following his arrival in Los Angeles (in 1925), he travelled several times to Japan, and during these visits he collected architectural drawings of recently-constructed buildings. ${ }^{7} \mathrm{He}$ also recorded these visits with multiple travel sketches. ${ }^{8}$ Knowing that Neutra was a long-time student of Japanese design, David Engel invited him to write the forward to his 1959 book Japanese Gardens for Today, in which Neutra demonstrated his great respect for, and 
erudite study of, this Asian tradition. ${ }^{9}$ He also left unpublished manuscripts on the subject of Japanese architecture and design. ${ }^{10}$ In addition to Japan, Neutra was also fascinated by the indigenous architecture of Africa, central Asia and the Indian subcontinent, as well as the shared history and traditions of California, Latin America and Spain. His study of the architecture of these traditions, combined with his exposure to Otto Wagner, Adolf Loos, Josef Maria Olbrich, Josef Hoffmann, Erich Mendelsohn, Louis Sullivan, Holabird and Roche and Wright himself, constituted what he called a 'mixed-up paternity' that deeply affected his view of the relationship between historic and Modern forms. ${ }^{11}$

From this plurality of sources, Neutra had also learned to appreciate open-air living and direct connection between human beings, architecture and nature. Inklings of a nascent interest in nature and life in the outdoors can already be seen in a few of Neutra's earliest travel sketches dating from the early 1910s, as well as in his 1915 design for an officers tea house, which was constructed in Trebinje, Albania. From Otto Wagner, Neutra had learned 'to cherish the site, and to give allegiance to the wider surrounding landscape'.12 Barbara Lamprecht has determined that, as a young man in Vienna, Neutra had studied Gestalt psychology, from which he learned that architecture can be used to manipulate human perception of space; ${ }^{13}$ similarly, from German psychologist Wilhelm Wundt's Principles of Physiological Psychology (1874), he had learned about human physiological responses to the environment. ${ }^{14}$ In 1919, while employed in Stafa, Switzerland, with Otto Froebel's plant nursery and landscaping firm, he came into contact with Gustav Ammann, who introduced Neutra to botany and landscape architecture. ${ }^{15}$ His fascination with these professions was evident in his work in the early 1920s, including his landscaping scheme (1921-24) for Mendelsohn's Einstein Tower in Potsdam, his design (1922) for the Forest Cemetery in Luckenwalde (Germany) and two private residential gardens (both 1922) in Berlin, one for Ernst Freud, and the other for the parents of Ernst's wife, Lux. ${ }^{16}$

Throughout his career, Neutra's architectural drawings and travel sketches reveal this obsession with natural elements. Stylistically similar to the landscapes painted by Gustav Klimt, whom he had known personally, Neutra's own renderings of natural elements such as vegetation, sky and clouds are often in a heavy, romanticized and highly textured manner, which can even obscure the architecture itself. ${ }^{17}$ Wright was also an obvious source in Neutra's developing ideas of connecting architecture to landscape. In his autobiography, Neutra recalled that, even prior to arriving in the American Middle West and to living and working with Wright at Taliesin (in 1924), he had already begun to romanticise about the region's landscape and the ways in which Wright had woven architecture and nature together in an indissoluble relationship. ${ }^{18}$ Neutra's ability to acknowledge local culture, tradition, climate and landscape in his architectural design had thus begun developing long before his arrival in Southern California in 1925 .

It was in Southern California, however, that Neutra found a new cultural, climatic and historic context that would serve as a key reference in his work throughout his career. From his arrival there until his death in 1970, he researched the historic architecture and the diverse cultures of the American Southwest, Latin America and Spain, and 
applied what he learned in his own work. In order to illustrate that aspect of Neutra's approach, this article consults several archival sources: unpublished manuscripts kept in the Richard and Dion Neutra Papers at the University of California, Los Angeles (UCLA); articles that Neutra wrote on Spanish and Latin American topics for publication both in North American journals, such as Architectural Forum, Progressive Architecture and House and Home, and in Spanish journals, such as Boletin de Información de la Dirección General de Arquitectura and Informes de la Construcción; articles written about Neutra by Spanish or Latin American authors, such as Francisco Prieto Moreno (Spain), Carlos Obregón Santacilia (Mexico) and Gregori Warchavchik (Brazil); ${ }^{19}$ books that Neutra published, such as Architecture of Social Concern (1948), Survival through Design (1954), Life and Human Habitat (1956) and Realismo biológico: un nuevo renacimiento humanístico en arquitectura (1958). ${ }^{20}$ This article will also pay attention to the multiple travel sketches that Neutra used to document his journeys throughout the American Southwest, Latin America and Spain, ${ }^{21}$ and to the projects - both built and unbuilt - that Neutra designed for clients in Spain and Latin America.

\section{'CALIFORNIA CALLS YOU': SPANISH COLONIAL MEETS INTERNATIONAL STYLE}

In his 1962 autobiography, Neutra admitted that, like Loos, he had been drawn as a young man to the United States in part by the technological innovations of the American industrial system. ${ }^{22}$ This fact is clear in his first published books Wie Baut Amerika (1927) and Amerika (1930). ${ }^{23}$ For this reason it was inevitable that Neutra would travel first to the industrial capitals of New York (October 1923) and Chicago (February 1924). Nonetheless, these cities were clearly not the 'idyllic tropical island' of which he had dreamt while living in Central Europe, 'where one does not have to fear the winter ... [and] can have a free spirit'. ${ }^{24}$ Instead, as Thomas Hines has pointed out, Neutra's ultimate destination in the United States had always been the warm-climate regions of California. ${ }^{25}$ Neutra himself remembered that, while strolling one day along Bahnhofstrasse in Zurich, he passed the window of a travel agency that displayed a poster with the slogan 'California Calls You'. ${ }^{26}$ Despite his thenrudimentary English, he understood the message: ' $\mathrm{I}]$ put two and two together and concluded that I was supposed to come to California. ${ }^{27}$ For him, 'Los Angeles was a very peculiar spot and vantage point. It was clear that this romantically Spanish colonial country of California might [...] become a prototype industrial and research area', and that it would 'turn out [to be] the most contemporary southland in search of a way of life for this day'. ${ }^{28}$

In 1960, Esther McCoy noted that this southward gaze typified Neutra's persistent search for timeless source material that he could merge with Modern architecture: 'his architecture is an eternal search for the southland, [the] cradle of civilization'. ${ }^{29}$ Neutra's books such as Architecture for Social Concern (1948), Survival Through Design (1954), Life and Human Habitat (1956), Realismo biológico (1958) and Life and Shape (1962), demonstrate his attraction to, and first-person familiarity with, warm-climate regions around the globe, and in these texts he made regular mention of places as geographically diverse as the Caribbean, sub-Saharan Africa and Polynesia. According to Lamprecht, he traced human origins back to the African savannah, and he believed 
that every modern human being innately longs for this place of origin. ${ }^{30} \mathrm{He}$ believed that humankind

loves to immigrate to the south, or to conquer it. [...] Like all Nordic barbarians we want to go to sunny Hellas, or to the land where the lemon blooms and no icy storms trouble us. ${ }^{31}$

Thanks to its bucolic climate, Neutra likened Southern California to the savannah, as if it were the New World version of this place of origin. ${ }^{32}$

Neutra's early interest in the American Southwest and Mexico was evident in his transatlantic correspondence with Schindler prior to emigrating to the United States. While central Europe was quickly descending into war at a continental scale, Neutra kept abreast of political developments in the Mexican Revolution. In a letter to Schindler dated 4 May 1914, he expressed his admiration for Schindler's early successes in America, as well as the advances then being made by the 'Mexican insurgents', quipping that, if Schindler's successes in the New World continued, he would soon replace Victoriano Huerta as Mexico's president. ${ }^{33}$ Neutra's reading of current events in Mexico had been acutely prescient as, just two months later, Huerta resigned. Neutra's interest in Mexico and the American Southwest seems to have originally been stirred by Schindler's report of his own tour, in August and September of 1915, to Denver, Salt Lake City, Taos, Santa Fe, the Grand Canyon and Los Angeles; on this tour, Schindler also visited the Panama-California Exposition in San Diego and the Panama-Pacific Exposition in San Francisco. ${ }^{34}$ Neutra's response contrasted the dismal situation of Europe, then in the midst of the First World War, with the relative peace and calm he idyllically imagined Schindler to be enjoying in the American Southwest: 'You are on the Mexican border and we bang away at each other mechanically each half year' ${ }^{35}$ Later, when Neutra wrote to Schindler to request a description of outstanding American architecture other than that of H.H. Richardson, Wright and Sullivan, Schindler responded that there was no such thing as American architecture, since skyscrapers 'have nothing human about them', and the rest of the architecture produced in the United States adhered to European styles that were imported to the New World. ${ }^{36}$ Instead, for Schindler,

the only buildings which testify to the deep feeling for soil on which they stand are the sunbaked adobe buildings of the first immigrants and their successors-Spanish and Mexicanin the Southwestern part of the country. ${ }^{37}$

It was upon arriving in Los Angeles in 1925, as Lauren Weiss Bricker has pointed out, that Neutra discovered that by the beginning of the twentieth century architects of the American Southwest had developed an acute awareness of the natural landscape of the region. ${ }^{38}$ This awareness had arisen principally from the work of naturalist John Muir (1838-1914) and the creation of the National Parks. ${ }^{39}$ This interest in nature was compatible with the values Neutra had inherited from fin-de-siècle Vienna, and he visited many of the National Parks in person: the Grand Canyon in 1925 (en route from Taliesin to Los Angeles); ${ }^{40}$ Joshua Tree in 1938;1 Death Valley in 1939 and 1957; ${ }^{42}$ Zion in $1951 ;{ }^{43}$ and Yosemite (date unknown). ${ }^{44}$ He demonstrated his appreciation for the natural beauty of the National Parks in his Visitor's Center (1961) at the Painted Desert and Petrified Forest in Arizona, designed in partnership with Robert 
Alexander. They organised the rangers' homes in tight groupings in order to provide mutual shelter and conservation of resources, and they employed interior patios in order to provide sunlight and fresh air, while still protecting the privacy of the individual residents. ${ }^{45}$ Neutra himself attributed these strategies to the lessons he had learned from the architecture of the Pueblo and Spanish Colonial heritages. ${ }^{46}$

Prior to his arrival there in 1925, Neutra's dreamy concept of Southern California had been a by-product of his own conjecture, his desire for warm climates, vague reports sent to him by Schindler and the propaganda of travel agencies. Although tenuous, this notion was squarely in line with what Carey McWilliams, writing in 1948, called the 'fantasy heritage' that had been imagined by a white majority to endow the region with an identity specific to itself. ${ }^{47}$ Matthew Bokovoy has described this phenomenon as anti-historic, and states that it had been invented for the economic development of Southern California. ${ }^{48}$ Phoebe Kropp has pointed out that, although not entirely fabricated, such a sentimental attitude had resulted from selective interpretations of the region's history by its various constituent groups, and that it had reflected the dual need to respect local history and to establish for Southern California a unique sense of identity. ${ }^{49}$

When Neutra arrived in Los Angeles in 1925, he discovered that most buildings designed and built in the region in the previous years tended to follow the lead of Bertram Grosvenor Goodhue (1869-1924) and the highly romanticised 'Spanish Style' of his Panama-California Exposition in San Diego (1915). ${ }^{50}$ This resurgence of interest in California's and Mexico's shared colonial past was not always the result of mindless mimicry. Cristina López Uribe has pointed out that architects on either side of the border often deliberately blended local historic forms with a sensitivity to materials and function, inspired by both Rationalism and the Arts and Crafts movement, which had been imported from Europe and the American Middle West; she also concluded that, in the 1920 s and 1930s, architects from Mexico and California, including José Villagrán Garcia, Enrique del Moral, Carlos Obregón Santacilia and Luis Barragán, had not merely used the old colonial forms 'in a nostalgic revivalist spirit, but also sometimes reframed them within a modern conception'. ${ }^{51}$ In a similar vein, Kropp has noted that

California's popular Spanish past is a 'memory box' full of varied, individual contributions, some of which represent competing narratives. It is a collection to which Southern Californians return again and again to assemble regional meanings. ${ }^{52}$

Following a comparable track, Neutra would demonstrate by the 1930s the agility with which he could enhance the Modernist ideas he had learned in Central Europe and the American Middle West with a sensitivity towards the local landscape, history and traditions of the American Southwest. His son and collaborator, the architect Dion Neutra, has attributed this responsiveness to Neutra's abstract interpretation of the inherent spatial qualities of Spanish Colonial architecture, and to his ability to transcend formalist mimicry. ${ }^{53}$ Dion has also noted that, when clients would hire his father to design a 'Spanish-Mediterranean' house for them, he would probe the client to identify the spatial qualities of this style that the client would find most appealing; and he would 
then use those spatial qualities as the generative idea for a house that surpassed questions of style, while still fulfilling the client's requirements. ${ }^{54}$ According to Hines,

it was typical of Neutra and his generation that except occasionally in the most minimal abstractions, their attempts to recapture the area's rich Hispanic tradition included no allusions to Spanish Colonial architecture in any explicitly communicable form. ${ }^{55}$

As Neutra searched for ways to create Modern forms using the local and vernacular architecture of the American Southwest, he discovered precedents in Wright's Californian work, as well as in that of three other émigrés, whose arrivals on the West Coast had preceded Neutra's: Schindler, Irving Gill (1870-1936) and Gordon Kaufmann (1888-1949). Wright's work, which Neutra had first seen in 1914, in the pages of the Wasmuth Portfolio, was always a source for Neutra. ${ }^{56}$ The house for Aline Barnsdall on Olive Hill in Los Angeles (1921) and the textile block houses (Los Angeles and Pasadena, 1923-24) were particularly important in this transfer, since they had all been projects under development at the time when Neutra was working for Wright. ${ }^{57}$ In these projects, Wright clearly referenced sources extracted from the American Southwest, claiming in his Autobiography that the Barnsdall House was 'conceived and desired as a California Romanza'. ${ }^{58}$ According to Wright's son Lloyd, Wright depicted Aline Barnsdall as an 'Indian princess' in the abstract relief he designed above the fireplace; Lloyd also stated that the house's forms followed Pueblo architecture. ${ }^{59}$ Donald Leslie Johnson has agreed, citing the architecture of the Navajo, Walpi and Pueblo Indians as Wright's sources for the Barnsdall and the textile block houses. ${ }^{60}$ Alice Friedman, moreover, has cited the adaptability of Pueblo architecture to the arid climate of the American Southwest, as well as the theatrical qualities of interior-exterior spaces found in Pueblo settlements, as likely reasons why Wright chose this architecture as a source for the Barnsdall House. ${ }^{61}$ Schindler, who oversaw the design and construction of these Southern Californian projects in Wright's absence, later recalled that, in designing the Barnsdall House, Wright was clearly thinking about Maya sources. ${ }^{62}$

In 1915, after Schindler had visited the expositions in San Diego and San Francisco and the pueblos of Taos (New Mexico) on his first travels through the American Southwest, he returned to Chicago and began to experiment with this fusion in a scheme for an adobe house (unbuilt) he designed that same year for Dr T.P. Martin in Taos. ${ }^{63}$ In this scheme, Schindler reinterpreted the changing levels and vertical connection of interior spaces of Loos's Raumplan according to the spatial sequencing he discovered in Taos. ${ }^{64}$ Later schemes followed a comparable approach. The model he constructed in 1916 during the initial design phases of the Hampden Club (Chicago), which he designed while employed by the firm Ottenheimer, Stern and Reichel, likewise reflected the lessons he had learned from Pueblo architecture. ${ }^{65}$ Robert Sweeney and Judith Sheine have described the tilt-slab concrete walls of his Schindler-Chase House in Los Angeles (1921) as a translation of the lessons he had learned on his 1915 tour of the American Southwest. ${ }^{66}$ His Pueblo Ribera Courts in La Jolla (1923) were likewise inspired by his 1915 visit to Taos. ${ }^{67}$ According to McCoy, this fusion then became a hallmark of Schindler's work in the 1930 . ${ }^{68}$

Irving Gill was also a source for Neutra. Upon arrival in Los Angeles in 1925, Neutra enjoyed 'exploring Southern California and discovering, in particular, Gill's abstract 


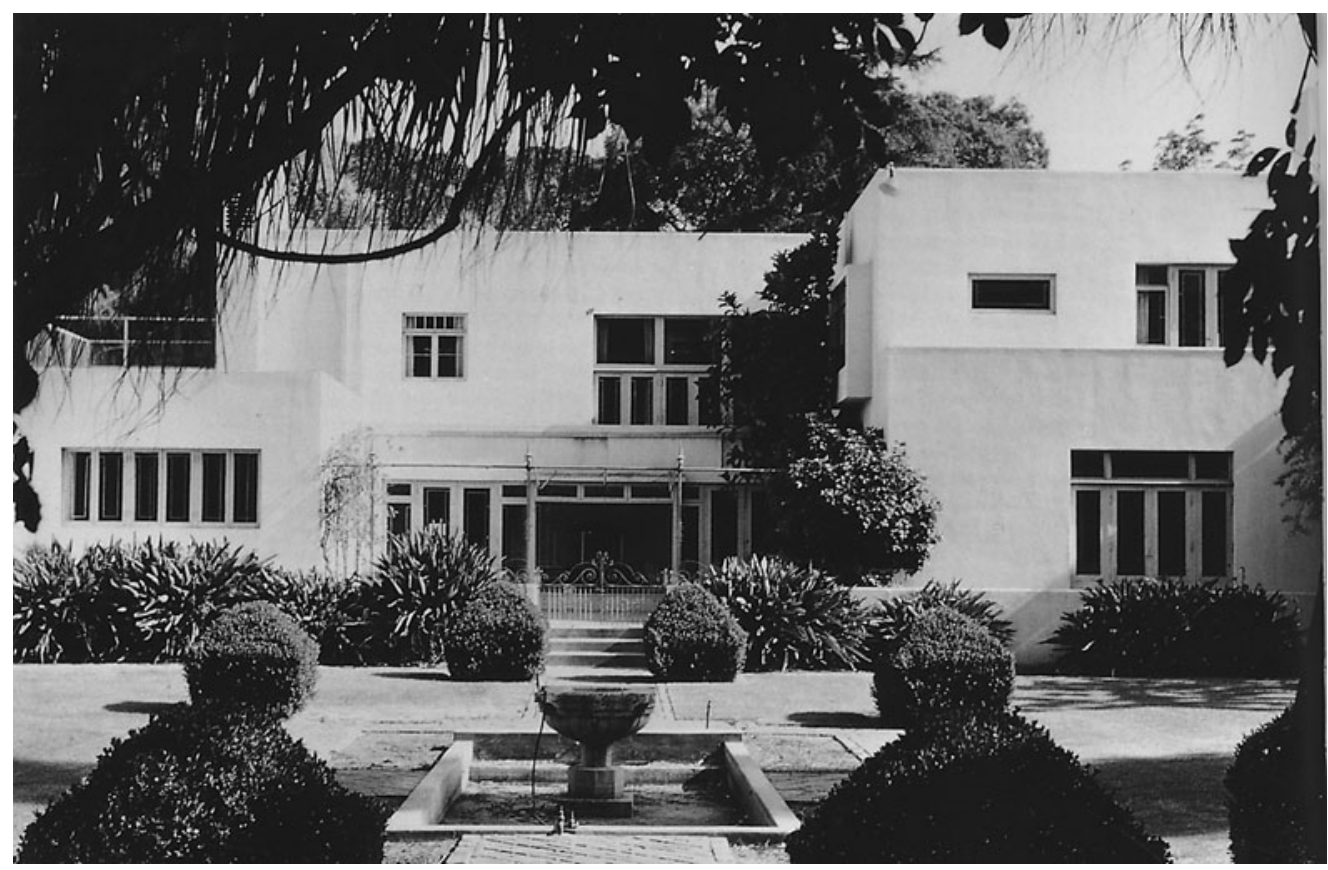

Fig. 1. Los Angeles, Irving Gill's Dodge House, main entrance (photograph by Thomas Hines; with permission)

early twentieth-century interpretations of Spanish Colonial architecture' ${ }^{69}$ His journey to Southern California in 1893, moreover, had prefigured Neutra's own: both men arrived in California after brief periods in New York and Chicago, where both had been connected with Sullivan and Wright. ${ }^{70}$ Neutra, like Schindler, also noticed striking formal similarities between Gill's works and those of Loos. ${ }^{71}$ Both Gill and Loos had been inspired by Sullivan's work and theories, and the two may have met personally in Chicago during Loos's visit to the Middle West, precisely when Gill was employed in Sullivan's studio. ${ }^{72}$ It was Gill's austere, white, cubic forms that reminded Neutra and Schindler of the work of their Viennese mentor, and provided them with evidence that Modernist ideas could be merged with the vernacular forms of Southern California and the American Southwest. One of Gill's most noteworthy buildings, the Dodge House (1914-16; Fig. 1), was located at 950 Kings Road in Los Angeles, only a few blocks from the Schindler-Chase House (835 Kings Road), where Neutra lived with his family for the first five years of his career in the city. Hines has suggested that the flat roofs, ribbon windows, stuccoed façades and lack of ornament of Gill's Dodge House, and also his Banning House (Los Angeles, 1910) and the Horatio West Court (Santa Monica, 1919), demonstrated to Neutra a successful blending of the lessons he had learned from Loos with the forms of the Spanish Colonial style. The Dodge House made a particularly lasting impression on Neutra, ${ }^{73}$ and in 1970 he ardently, yet ultimately unsuccessfully, protested against the building's demolition. ${ }^{74}$ 

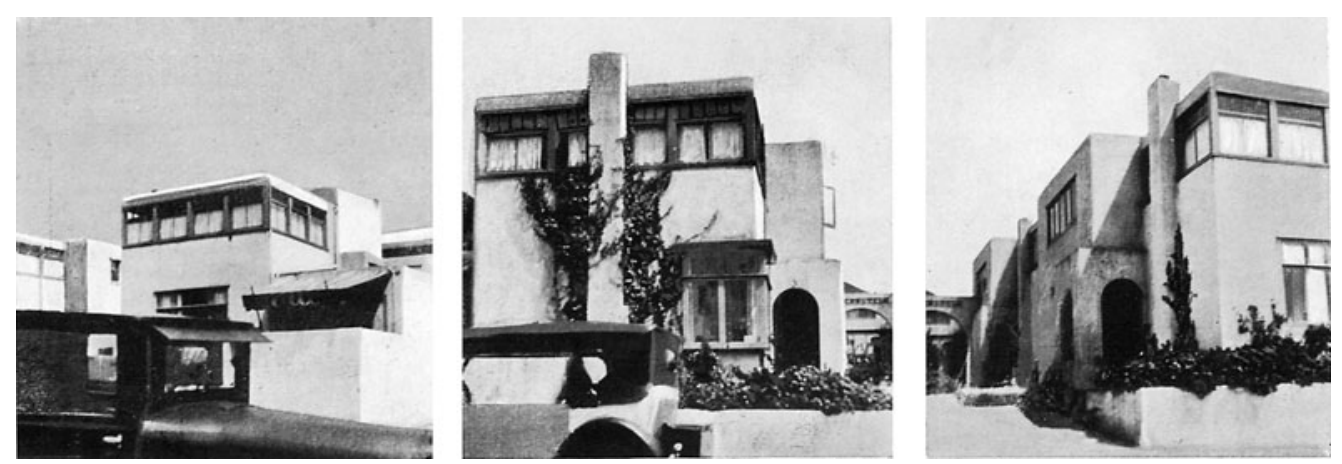

Fig. 2. Santa Monica, Irving Gill's Horatio West Court (photographs by Richard Neutra ca. 1929; from Neutra, Amerika; courtesy Dion Neutra, Architect (C) and Charles E. Young Research Library, UCLA)

One of Gill's early Southern California commissions (received in 1899) had been the restoration of the San Diego Mission, an authentic specimen of the austere, Franciscan variety of the Spanish Baroque. Gill's investigation of this building became a pivotal moment in his career, and his subsequent projects increasingly appropriated elements of this historic style. ${ }^{75}$ While working on this project, however, Gill also studied the Spanish Colonial style; both the archival evidence and Gill's body of works demonstrate that he purposefully avoided historicist mimicry, as noted by Gill's contemporary George Wharton James:

Early impressed by the wonderful climate and scenic environment of California, he sought, not as so many architects have done, to imitate [...] but to absorb [...] the original sources of their inspiration. ${ }^{76}$

As Hines noted, at its core, Gill's unique version of Modern architecture represents a search for 'the contemporary implications of California's Hispanic architectural legacy'. ${ }^{77}$ As for Neutra, he was so impressed by this fusion that, in 1930, he used his own photographs of Gill's work to illustrate his second full-length publication, Amerika (Fig. 2). ${ }^{78}$

In order to provide for his growing family, Neutra took employment in 1925 with the English-born architect Gordon Kaufmann, who had arrived in California in 1914. ${ }^{79}$ This architect also made a considerable impression on Neutra. In the early 1920s, Kaufmann had collaborated with Reginald Johnson and Roland Coate, and from Johnson he had learned to appreciate Goodhue's use of the Spanish Colonial style in the 1915 Panama-California Exposition in San Diego. ${ }^{80}$ Cristina López Uribe has recognised that since the First World War, when travel to the Mediterranean Basin was not feasible, the so-called 'Spanish Colonial' had provided Californians with a locally available 'Mediterranean' theme. ${ }^{81}$ Consequently, following his separation from Johnson and Coate in 1924, Kaufmann adopted a style of architecture that was loosely Mediterranean; 82 Neutra described it as following the 'early Florentine Renaissance style', and reminisced that 'the marvelous large illustrated publications that form the source material awaken my longings for Italy. ${ }^{\prime 83}$ It was while he was employed in 


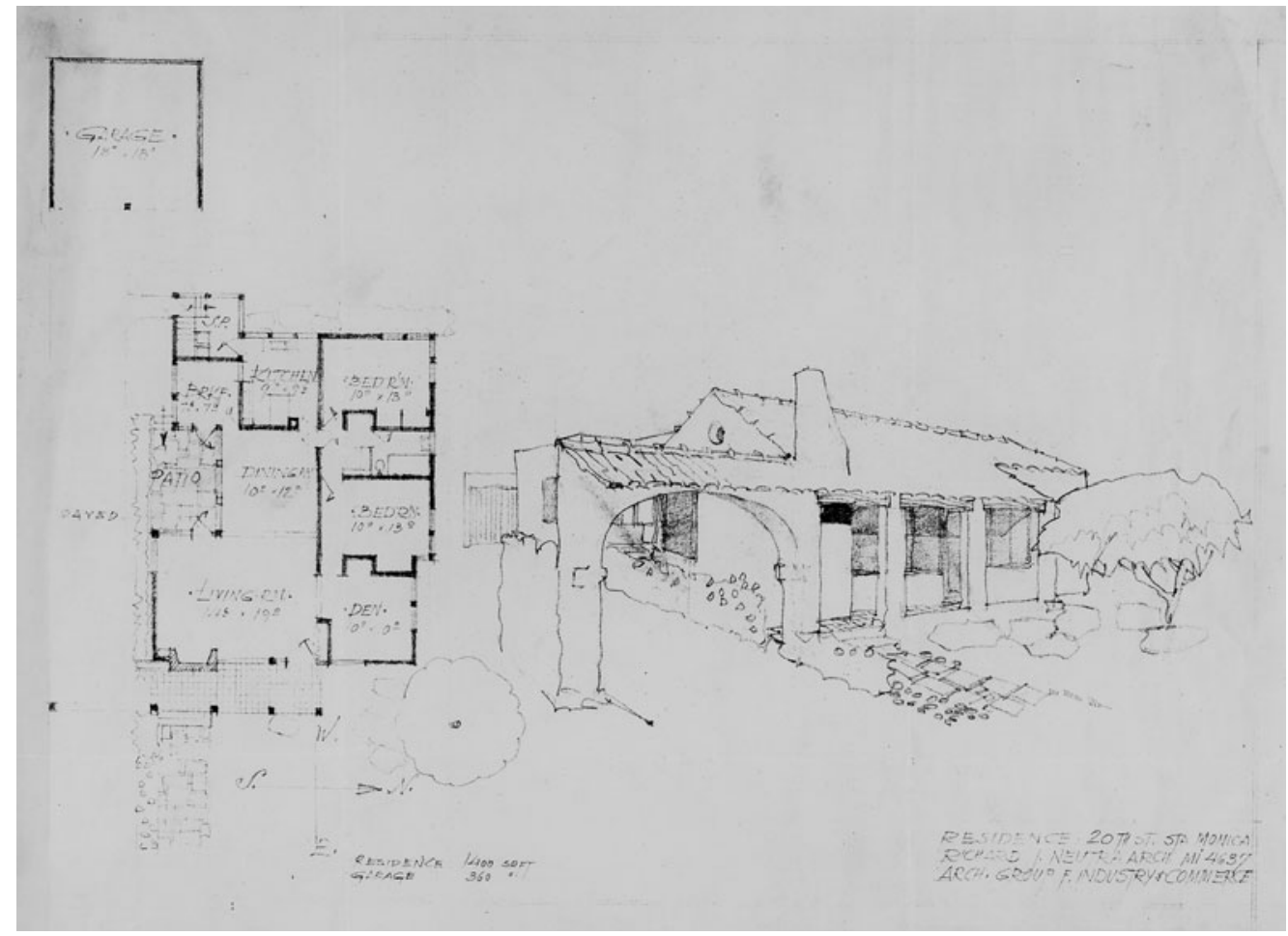

Fig. 3. Richard Neutra, sketch for a single-family house (c. 1927; unbuilt) in Santa Monica (courtesy Dion Neutra, Architect (C) and Charles E. Young Research Library, UCLA)

Kaufmann's studio that he produced working drawings for the Eisner House in Los Angeles (1925), 84 a building that features reflecting pools, clay tile roofs, whitewashed stucco walls and three vegetated interior courtyards. ${ }^{85}$ Yet he continued to hold Kaufmann in high esteem, in spite of the fact that Kaufman's 1920s projects quoted the historic styles of the faraway Mediterranean region quite literally, and he did so even long after resigning his post in Kaufmann's studio.

During the first decade of his Los Angeles career Neutra designed a series of projects that reflect the ongoing maturation of his own modernist aesthetic. In addition to his well-known projects in Los Angeles for the Jardinette Apartments (1927) and the Lovell Health House (1927-29), he produced a competition entry (designed with Schindler) for the League of Nations Building in Geneva (1926), a series of drawings for the urban utopia that he called 'Rush City Reformed' (mid-1920s), as well as the unbuilt schemes for the Colton Theatre (1927) and a skyscraper for the National Trading Centre (1927), both in Los Angeles. ${ }^{86}$ At the same time as he was developing these avant garde projects, however, he also followed the examples set by Wright, Schindler, Gill and Kaufmann in seeking a potential synthesis between his own Modern ideas and the architecture of California's colonial past. In 1927, the same year he was working on the Jardinette Apartments and the Lovell Health House, he 
supplemented the insufficient wages he was earning from Kaufmann by designing several small houses (unbuilt) for properties in and around Santa Monica (Fig. 3). ${ }^{87}$ These houses, with their arches, loggias, whitewashed stucco and pitched roofs clad in clay tiles, exchanged the modernist aesthetic for stylistic experimentation with Spanish Colonial forms.

A similar attempt to incorporate historic forms can be seen in the drawings made by Neutra and Schindler in 1928 for a civic centre in Richmond, California. ${ }^{8}$ Their description of this design indicates that they intended to reject the historicist mimicry of monumental civic buildings from the past, such as the Doge's Palace in Venice or the Baths of Caracalla in Rome, ostensibly because 'we are now living in a mechanical, rational, abstractly imaginative age and our architecture should bear the imprint of the age' ${ }^{89}$ Notwithstanding this claim, McCoy has pointed out that the design for these buildings was still deeply indebted to Goodhue's stylistic and planimetric formalism, and she also noted that

there was no trace of Mendelsohn in them, or Wright, or Schindler's early houses, or even the visions of flight found in Neutra's theoretical Rush City, which by then he had begun. The formalism of the layout would have puzzled Loos. ${ }^{90}$

Working on his own, Neutra also experimented with vernacular forms of the American Southwest in his never-constructed project for the California Lambs Club in Hollywood (1926) (Fig. 4), which he designed for the Fidelity Construction Company. ${ }^{91}$ Unlike the purely historicist styling of the houses in Santa Monica, for this project he juxtaposed Spanish Colonial and Modern forms: he superimposed heavy volumes - articulated in a way reminiscent of Wright's buildings such as the Imperial Hotel in Tokyo and the Larkin Building in Buffalo - over a much lighter base of porticoes and arcades. A promotional brochure advertised this work as 'extreme Spanish design'. ${ }^{92}$

In 1926, Neutra followed the stylistic hodgepodge of the California Lambs Club with his much more elegant, yet largely-unknown (perhaps because it was again unbuilt), addition to the Baum family house in Santa Monica (Fig. 5). ${ }^{93}$ The addition was designed as a Rationalist prism containing a gymnasium and a playroom. With its programmatic emphasis on wellness, physical activity and exposure to fresh air and sunlight through ventilated and louvred screens, as well as its flat roof, horizontal lines and lack of ornament, it was faithful to the Modernist agenda. However, it also complemented the existing Spanish Colonial quinta (a traditional country house), which Hines has noted

shows in its proportions and attention to detail how deftly Neutra could add a contemporary wing to a traditionalist structure without compromising the original building or his own modernist principles. ${ }^{94}$

Later, his admittedly less successful addition to the Rajagopals House in Los Angeles of 1934 (Figs. 6, 7 and 8) similarly represents his struggle to merge Spanish Colonial and Modern forms. ${ }^{95} \mathrm{~A}$ more sensitive juxtaposition of Modern and historic forms, however, occurred in the 1936 Ruben House in Los Angeles (although in this case the historic style was Shingle and not Spanish Colonial). ${ }^{96}$

Neutra's attempts to fuse the spirit of the architecture of the American Southwest with his own Modern ideas gradually shifted, from the formalistic mimicry of the Santa 


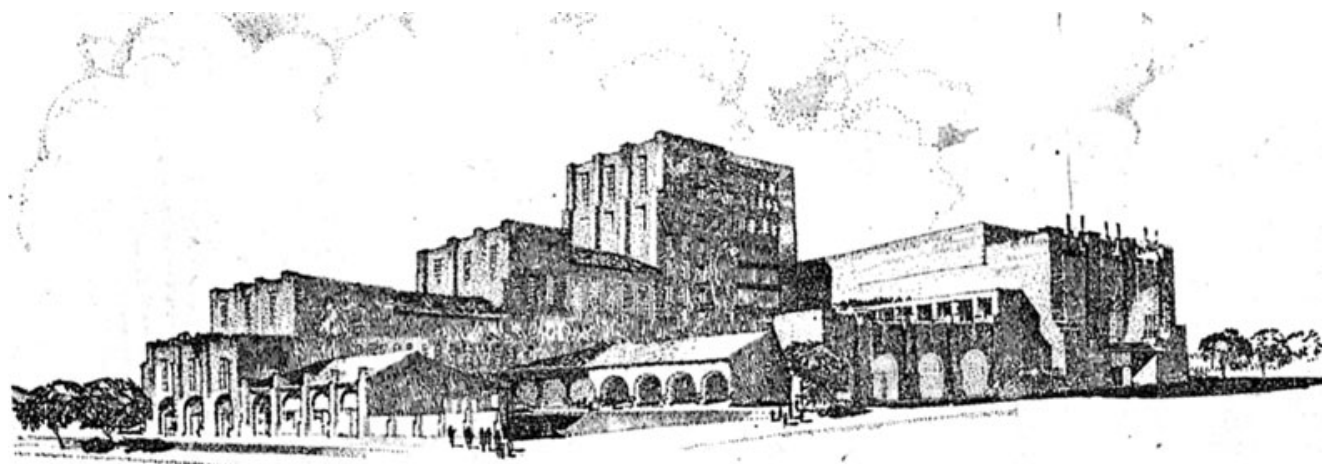

Fig. 4. Richard Neutra, sketch of the California Lambs Club (1926; unbuilt) in Los Angeles, as published in Dione Neutra, Richard Neutra, Promise and Fulfillment, 1919-1932 (courtesy Dion Neutra, Architect () and University of Southern Illinois Press)

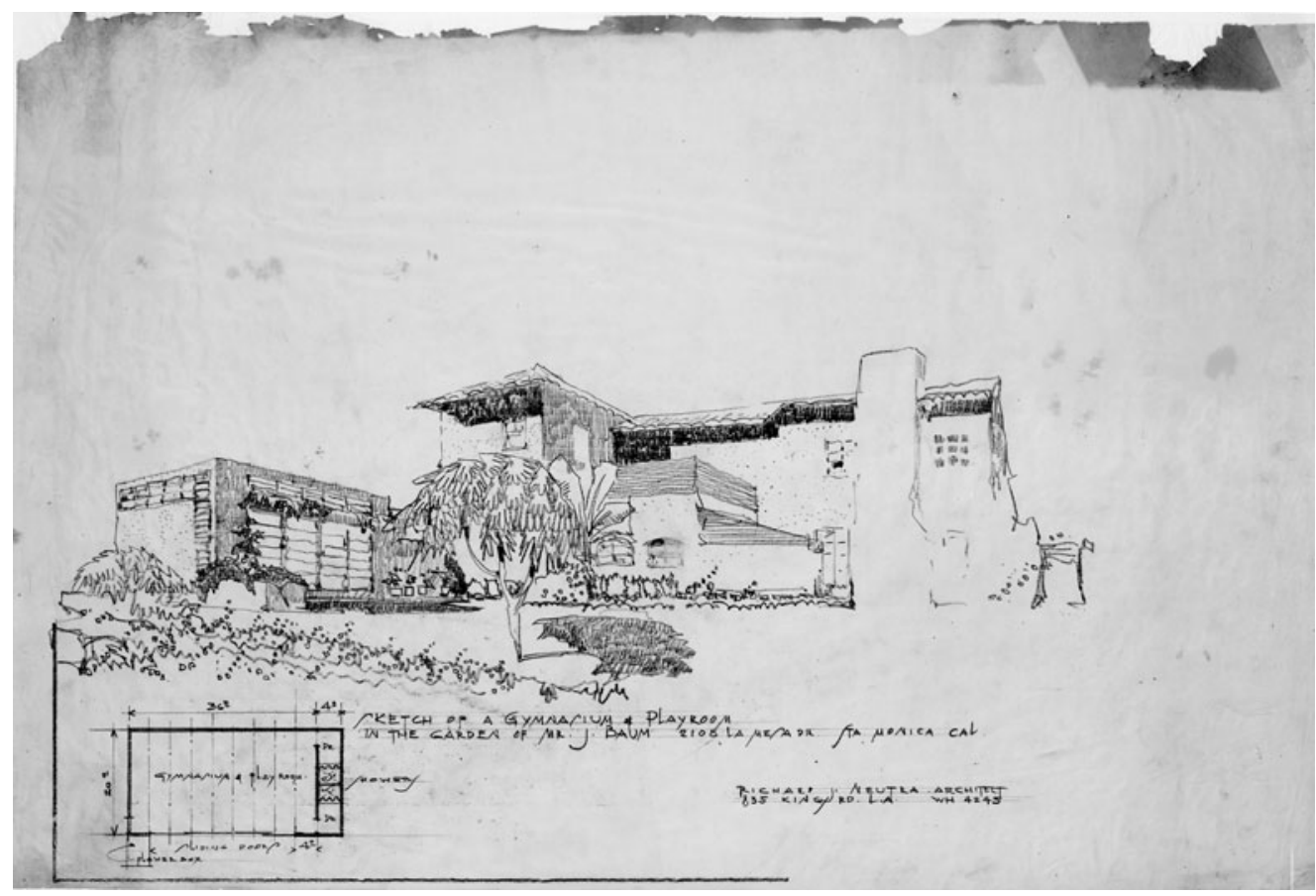

Fig. 5. Richard Neutra, sketch for the Baum family house showing the addition of a gymnasium (1926; unbuilt) in Santa Monica (courtesy Dion Neutra, Architect (C) and Richard and Dion Neutra Papers, UCLA)

Monica houses and sensitive juxtaposition of contrasting forms in the Baum House, to a more meaningful synthesis of Modern and traditional ideas. He had adapted vernacular Californian sleeping porches for use in the 1927-29 Lovell Health House, ${ }^{97}$ but in his Corona Avenue School of 1935 in Los Angeles he used abstract reference to 


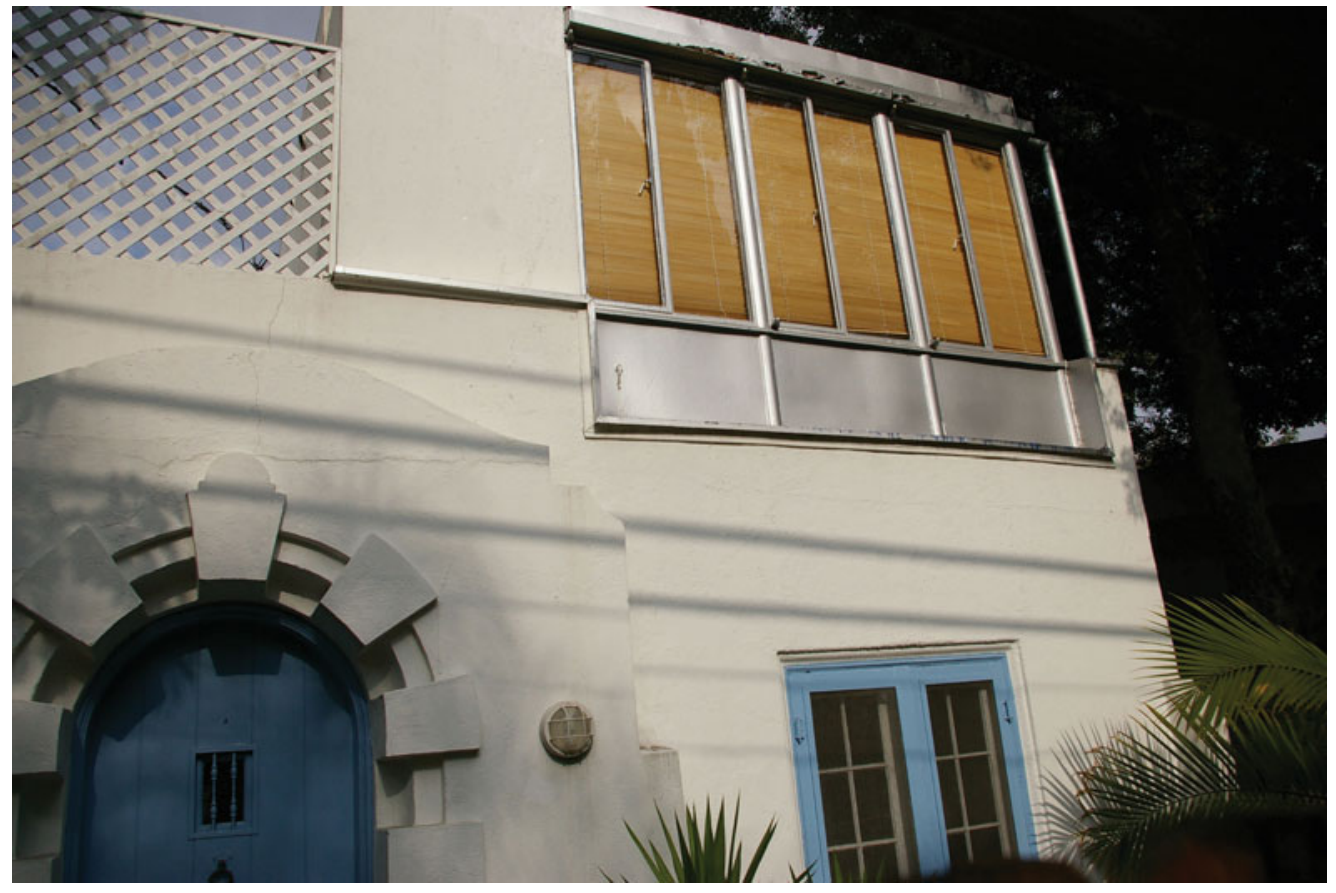

Fig. 6. Los Angeles, Richard Neutra's Rajagopals House, showing Neutra's second-floor addition in the upper right (author's photograph, 2009)

California's colonial architecture. Undoubtedly, he had climatic concerns and pedagogical innovation in mind when he designed the school's covered exterior pathways, which connect the individual classrooms. ${ }^{98}$ McCoy, however, has pointed out that they are also an interpretation of the 'arcaded passages' that were common in Spanish Colonial architecture. ${ }^{99}$ Other projects in Los Angeles, such as the VDL Research House (1932-39) and the von Sternberg House (1937; demolished), again deftly incorporate strategies from Spanish Colonial architecture, such as the patio (discussed further below). The forms of Neutra's Strathmore Apartments (1937) were also inspired, as Hines has noted, by Spanish Colonial architecture, and by the architecture of the cultures indigenous to the American Southwest:

Long impressed with the stacked mega-structures of the Pueblo Indians and of the more recent systems of courtyard housing in Southern California, Neutra designed Strathmore as a modernist updating of both vernaculars. ${ }^{100}$

In addition to his architectural designs, his travel sketchbook also reveals that, up to his death in 1970, Neutra continued to be intrigued by the vernacular architecture of the American Southwest, as well as by the Spanish Colonial and Baroque styles. On his many journeys through California and Latin America, he recorded views in his sketchbook of notable exemplars of this style, such as the San Juan Cathedral (Puerto Rico, 1540), Nuestra Señora del Carmen Church (Santo Domingo, 1615-1729), the parish 


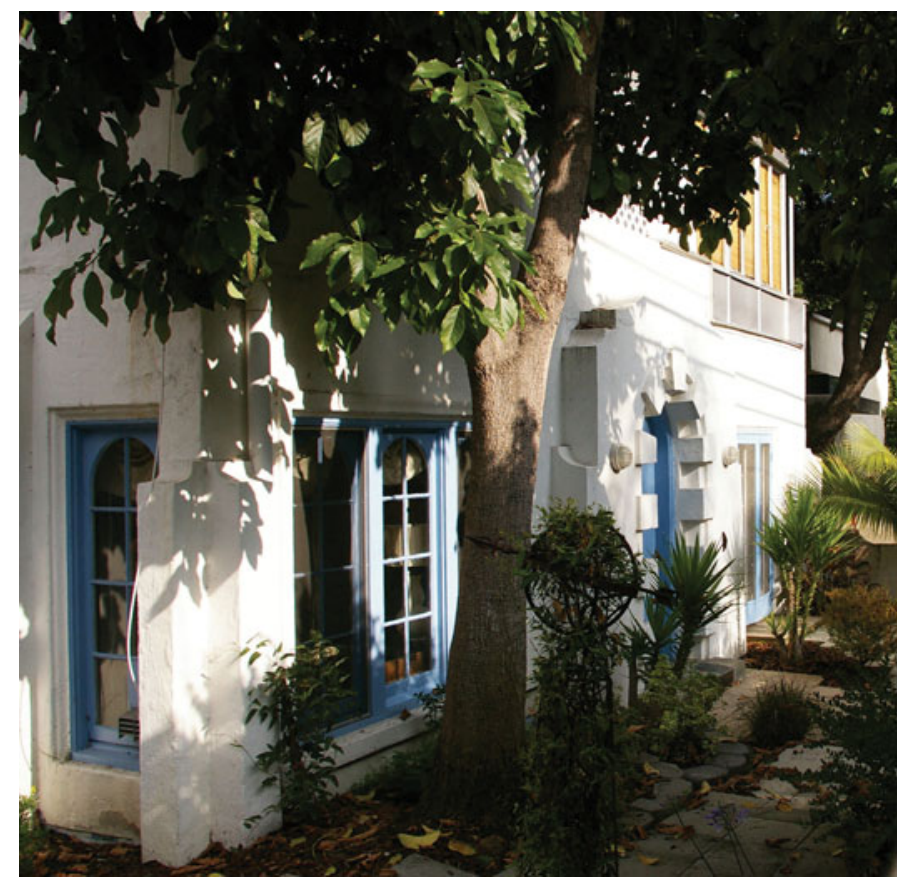

Fig. 7. Los Angeles, Richard Neutra's Rajagopals House (author's photograph, 2009)

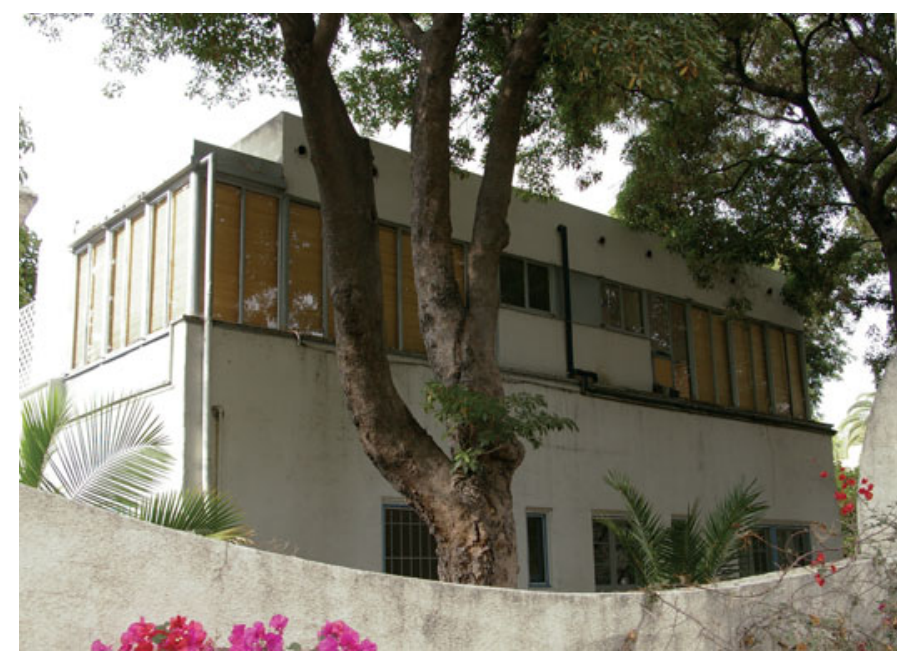

Fig. 8. Los Angeles, Richard Neutra's Rajagopals House (author's photograph, 2009)

Church of the Holy Spirit and San Patricio (Loiza, Puerto Rico, 1645), the Cathedral of San Cristobal (Havana, 1748-87), Mission San Antonio de Pala (Pala, California, 1816) and Mission Santa Inés (Solvang, California, 1817). ${ }^{101}$ Moreover, his interest in these cultures extended beyond architecture alone; his travel diary also includes many sketches of 
local cultural events, such as traditional dances, gauchos riding on horseback, bullfights and ordinary daily activities. ${ }^{102}$

\section{NEUTRA'S FIELD STUDIES IN LATIN AMERICA AND SPAIN}

As has been discussed by Lauren Weiss Bricker, architects practising in the American Southwest in the 1930 s were asked about their sources for inspiration. ${ }^{103}$ In response, they did not cite European architects but instead Japanese precedents and Latin American architects, such as Juan O'Gorman. They also cited local climatic, topographic and cultural conditions. It is therefore no surprise that Neutra, too, was inspired by the architecture created by the diverse cultures he encountered during his extensive travels throughout Latin America. During the 1930s, 1940s and 1950s he travelled to practically every continent, yet his archives and sketchbooks reveal that, along with Japan, the countries of Latin America and the Iberian Peninsula were among his most preferred and documented international destinations. His reasons for travelling extensively throughout Latin America are likely due to the historical connections between these regions and California, as well as to the personal connections he felt with the people of these places; for example, Neutra's son Dion remembers that his father was so interested in these cultures that, during his visits to Cuba, Venezuela and Puerto Rico, he made an effort to learn the Spanish language. ${ }^{104}$ In this way, Neutra distinguished himself from Wright, Gill and Schindler, who appear to have focused their studies of indigenous American architecture on the specific cultures of the Maya (in Wright's case), or the American Southwest (in Gill's and Schindler's). While Neutra did indeed study these cultures, his interests in, and references to, Latin American architecture also included other cultures, such as the Aztec and Inca civilisations, and extended southwards from Baja California and the Caribbean to as far as Tierra del Fuego.

Naturally, given his early interest in it even before emigrating to the New World, Neutra's first Latin American destination was Mexico. He claimed that:

As a child in Vienna I sang the anthem glorifying the last, long-lived ruler of the Hapsburg dynasty upon whose far-flung empire the sun at one time had never set. Mexico was the heart of it, and for me, a place of wonder. When I first saw Mexico many years later, I felt immediately at home. ${ }^{105}$

He first travelled to Mexico in 1925, only months after arriving in Southern California. On this first visit to Latin America, he was impressed by the canals and chinampas (floating gardens) of Xochimilco, which he documented in a travel sketch showing 'a man rowing a group of passengers on a flower-decorated Trajinera (boat)' ${ }^{106}$ He then continued to visit Mexico throughout the following decades. ${ }^{107}$ In 1935, he visited Mexico City and Toluca, ${ }^{108}$ and his third visit, in 1937, resulted from the invitation of Carlos Contreras to give a guest lecture in Mexico City; during this visit, Barragán arranged for him to tour Guadalajara and to participate in a conference in Chapala. ${ }^{109}$ In 1937, he also visited the pyramids in Mexico City, together with Frida Kahlo and Diego Rivera, whom, according to Hines, he 'had long admired'. ${ }^{110}$ He commemorated the encounter in a travel sketch (Fig. 9) that pictures Rivera and Kahlo standing in front of the Tenayuca Pyramid. ${ }^{111}$ Of the encounter he wrote: 
on the sunny street, I met the immense, the colossus Rivera and soon afterwards his diminutive, black-haired doll, his wife. [...] Finally we drive to Guadeloupe [sic] where thousands of Indians are on a pilgrimage from December 12th to observe the yearly Fiesta of the Holy Virgin. [...] On the way I see an excellent housing project as well as Aztec villages unchanged from a thousand years ago. Finally we reach the [...] fantastic pyramid encircled by granite stone snakes. Night falls as we carefully climb higher and higher, not wanting to break our necks on this steep incline. Then a long drive back in the darkness. We have a good time together. ${ }^{112}$

On that same visit, he attended a bullfight, which he recorded in a travel sketch entitled 'Una Tarde De Toros' (Fig. 10). ${ }^{113}$ He was particularly fascinated, however, by the Spanish Baroque architecture that he found throughout Mexico. He referred to Mexico City's cathedral as 'the greatest church in the world (except St. Peter's in Rome)' and he called the adjacent Zócalo 'the grandest plaza in Christendom'. ${ }^{114}$

Throughout these visits, Neutra was impressed by the ways in which Mexican architects had successfully synthesized Mexico's history and tradition with its increasing modernisation. During the 1937 visit he also met Juan $\mathrm{O}^{\prime}$ Gorman, who had already completed several projects, notably Rivera and Kahlo's house in Mexico City (1929-30), and who had served as Head of the Architectural Office of the Ministry of Public Education since the early 1930s. ${ }^{115}$ Neutra later visited other O'Gorman projects, not least his Central Library (1950-53) at the National Autonomous University of Mexico (UNAM, Mexico City, designed in collaboration with Gustavo Saavedra and Juan Martínez de Velasco), which Neutra saw in $1957 .{ }^{116} \mathrm{He}$ was also familiar with the works of José Villagrán García, who, from the mid-1940s to the mid-1950s, collaborated with O'Gorman, Enrique del Moral, Mario Pani, Carlos Lazo and others to design the campus and buildings of UNAM. ${ }^{117}$ In 1952, Neutra commended Villagrán García for building Modern architecture in Mexico as early as 1925, precisely the same moment as Neutra himself had been struggling to reconcile his own Modern ideas with the revival of the Spanish Colonial style that prevailed in California. ${ }^{118}$ Likewise, he probably also appreciated the fusion of Mexican history and Modern architecture that is evident in Pedro Ramírez Vázquez's acclaimed National Museum of Anthropology and History, which was completed in Mexico City in 1964, only months after Neutra lectured at the International Congress of Architects there, in 1963. ${ }^{119}$

During his visits to Mexico, Neutra discovered, as Obregón Santacilia has explained, that even in the earliest days of the colonial period, Mexican architecture had demonstrated a synthesis of the cultures of various indigenous groups and the Spanish colonisers. As evidence, Obregón Santacilia has cited examples of architectural ornamentation from buildings built across Mexico from the sixteenth to the nineteenth centuries. ${ }^{120}$ Neutra's appreciation of this fusion was plainly evident to Irving Myers, who, in 1950, was awarded a fellowship by the National Institute of Fine Arts of Mexico to study contemporary Mexican architecture, the result of which was his book of 1952 Mexico's Modern Architecture. ${ }^{121}$ In this book, he acknowledged Neutra 'for guidance, encouragement and inspiration over a period of years', and he invited him to write the introduction. ${ }^{122}$ There, Neutra remarked that, because of 'their consciousness of the past fused with the problems of the present', Mexican artists such as Rivera, Kahlo and $\mathrm{O}^{\prime}$ Gorman were unrivalled on the international scene, and that 'Mexico is beginning 
Fig. 9. Richard Neutra, Tan Yuka Pyramid/Serpent

Diego \& Frieda [sic] Rivera, Mexico City, 1937 (courtesy Dion Neutra, Architect (C) and Charles E. Young Research Library, UCLA)

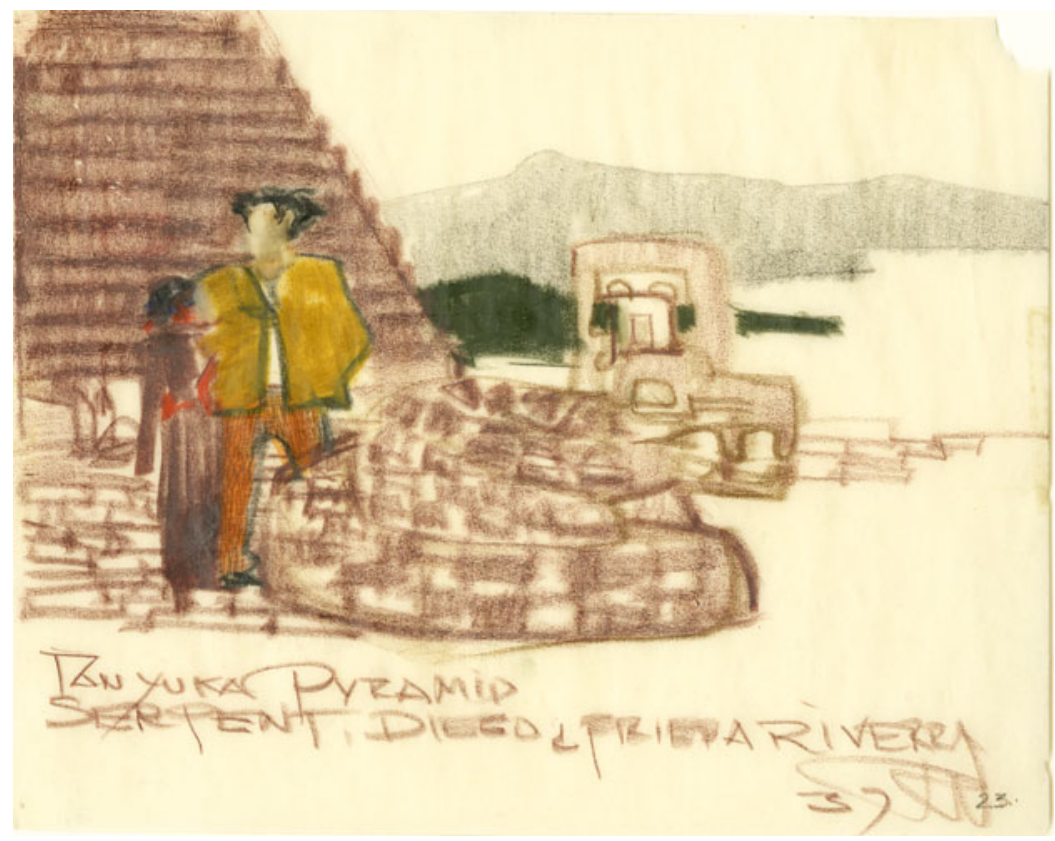

Fig. 10. Richard Neutra, Una Tarde De Toros, Mexico, 12 December 1937 (courtesy Dion Neutra, Architect (C) and Charles E. Young Research Library, UCLA)

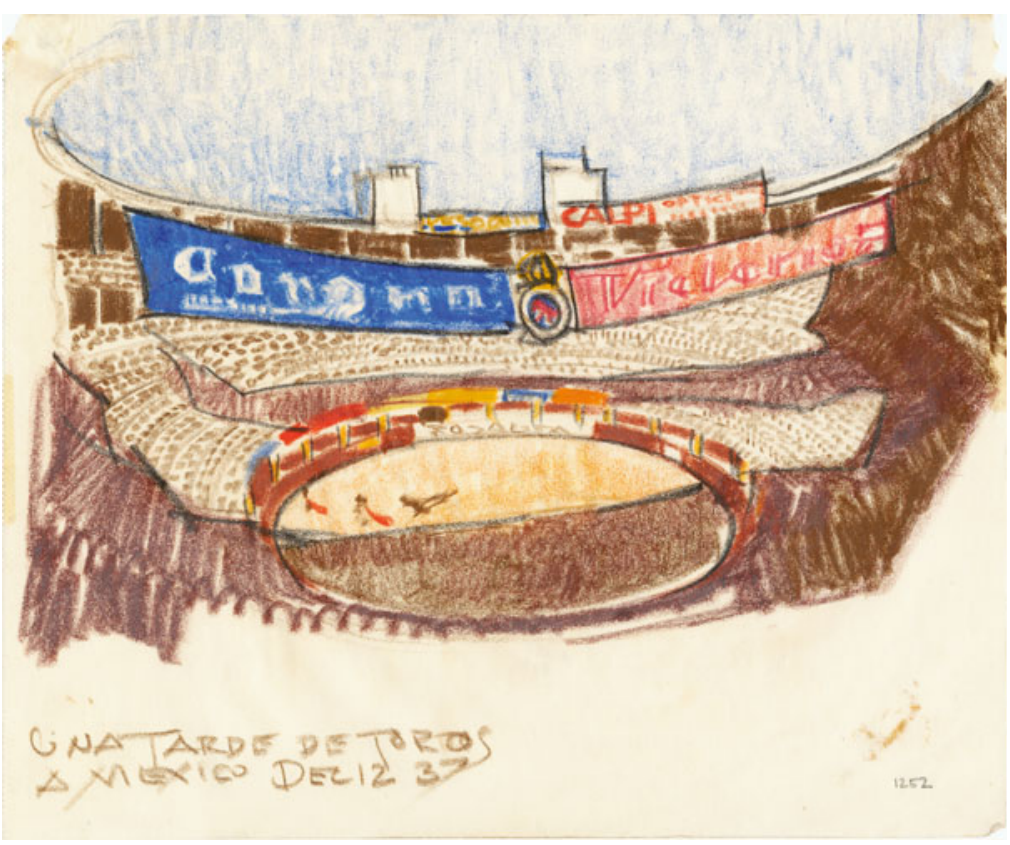


to take its deserved place in the civilization of industrial technology, [and] it has almost simultaneously rediscovered new values in its pre-European past. ${ }^{\prime 23}$

Geographically, Mexico was the Latin American country nearest to Neutra's home in Los Angeles, but it was not his only frequent travel destination south of the border. In the early 1940s, he was commissioned by the Committee on Design of Public Works of Puerto Rico, and specifically through the person of Rexford G. Tugwell, the island's governor. ${ }^{124}$ In this commission, Neutra served as lead architect for a comprehensive project to design prototypes for public facilities in Puerto Rico, including schools and rural health centres for more than 150 locations across the island, as well as five large hospitals, staff housing and a home for young girls. ${ }^{125}$

For the editors of Architectural Forum who, in 1945, ran a feature article on this project, Neutra had been the obvious choice for this commission, because of his 'unique design approach', in which 'architectural treatment was entirely compatible with the warm tropical climate'. ${ }^{126}$ In a 1944 article written by Neutra himself and published in Survey Graphic, he expressed the view that his appointment as this project's director of design had resulted from his own 'considerable experience as an architect in the tropics', which is clearly a reference to his work in other former Spanish colonies. ${ }^{127}$ Prior to the publication of this article in 1944, all of Neutra's built work in warm or semi-tropical climates had been located in California, Texas and Florida. ${ }^{128}$

As was the case in Mexico, Neutra was keenly interested here in the island's historic architecture and its people. The many travel sketches he recorded during several visits to the island in 1944 and 1945 include historic buildings such as small cottages and the San Patricio church (both in Loiza), as well as the Cathedral of San Juan. ${ }^{129}$ He also sketched several of the island's natural features, such as the El Yunque Forest, beaches and tropical vegetation. ${ }^{130}$ This two-year project, in addition, facilitated direct contact between him and the island's people, and he also developed professional relationships with Puerto Rico's most talented young architects. ${ }^{131}$ As for the buildings he designed for the island, these reflect his study of elements of local Puerto Rican culture. Thus, when planning the three prototypes for health centres, he situated the milk dispensary, a programmatic function that would serve as a natural community gathering point, between an enclosed children's play patio and an outdoor extension of the interior waiting room (Fig. 11). He described these twin exterior spaces as:

a spacious porch with a concrete bench running around it as a place for meetings, lectures, entertainments, and broadcasts for the mountain community. Our purpose was to avoid any institutional character, making these buildings genuinely belong to the people. Here they can play their dominoes, strum their guitars, and dance-and incidentally, learn something about child care, diet, and more practical housekeeping. ${ }^{132}$

Prior to his time in Puerto Rico, Neutra had used several small porches in single-family residences, such as the sleeping porches of the Lovell Health House and the VDL Research House, but he had never employed them to house community activity on a large scale. Subsequently, in his Eagle Rock Park Clubhouse (Los Angeles, 1953), designed in collaboration with his son Dion, he replicated these twin 'spacious porches' as two exterior spaces that flank the indoor community room and play hall (Fig. 12). As with the Puerto Rico health centres of the previous decade, these porches 


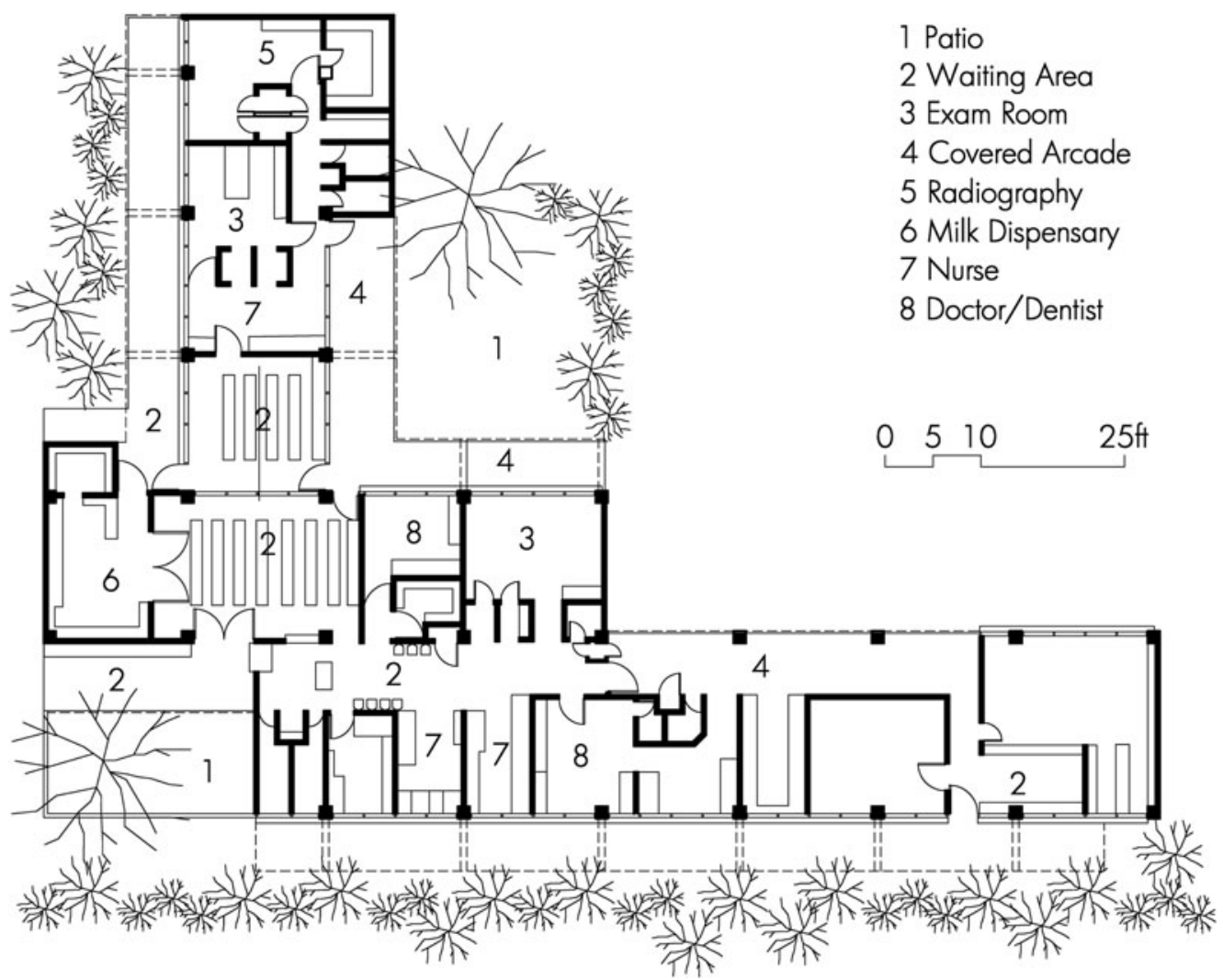

Fig. 11. Richard Neutra, plan of 'B' Type Urban Health Center, Puerto Rico, 1944 (as redrawn by author after the original)

were intended to provide flexible spaces that allow for diverse, everyday activities to occur, seamlessly, indoors and out. ${ }^{133}$ Echoing his own description of the 'spacious porches' in Puerto Rico, Lamprecht has described the porches at Eagle Rock as 'a delight for children playing underneath them in rain or sun'.134

Immediately following his work in Puerto Rico, in 1945, Neutra travelled throughout various regions in Latin America as an official envoy of the US Department of State (Fig. 13); and in 1946 he published his 'observations on Latin America' in Architectural Forum, whose editors declared 'that Mr. Neutra's opinions should be stimulating to both North and South American readers and [...] they have significant bearing on the over-all problems of planning in general'. ${ }^{135}$ Notwithstanding any covert political agenda the State Department might have had for this purportedly goodwill tour, Neutra himself had understood it as a mutual exchange of ideas, in which he had as much to learn from his Latin American counterparts as they did from him:

It is interesting to speculate on how much different cities and regions might profit from the exchange of ideas and comparison with the experiences of others. Such cross fertilization can 


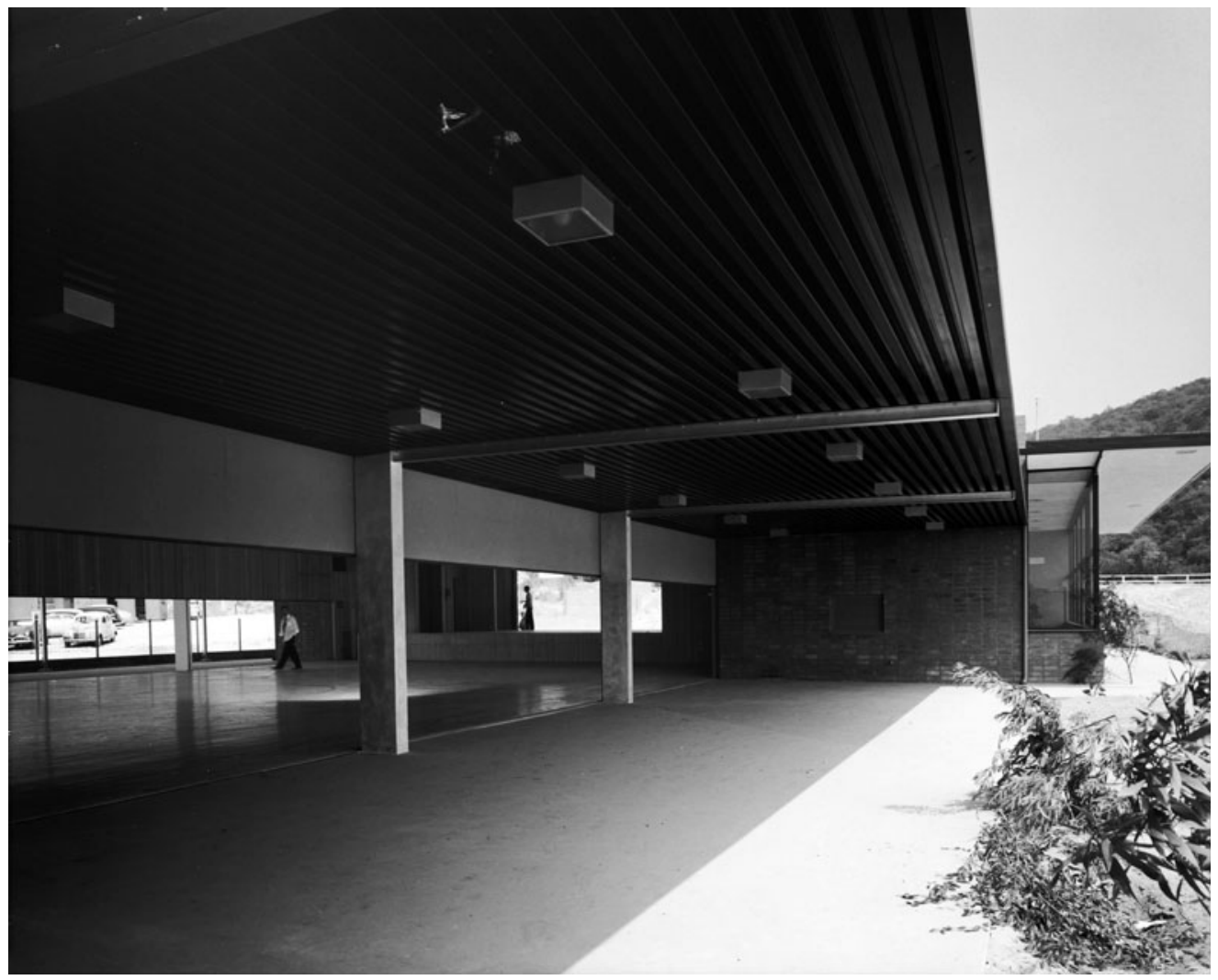

Fig. 12. Los Angeles, Richard Neutra's Eagle Rock Park Clubhouse, showing the 'play porch' along the building's east side (photograph by Julius Shulman; courtesy Dion Neutra, Architect (); and (C) J. Paul Getty Trust)

start with simple questions: What are the new problems with you and with us? On what might additional emphasis be placed here and there? What, outside of established local routine, might be tackled to advantage? ${ }^{136}$

Warchavchik likewise concluded that this tour was as instructive for Neutra as it was for Latin America's architects. He described Neutra as 'a receptive artist, whose crayon miraculously fixed pictorial notes into his travel sketchbook', and as a

deeply agreeable human being, irradiating his specific kind of sympathy, unselfishly helpful, a man warmly admiring the work of other creative men, and still-instinctively and without faltering-wandering along his own path and lifeline. ${ }^{137}$

The 'observations' Neutra made on this tour also reveal that he was impressed by advances currently being made in the region, such as Modern city planning strategies that included the progressive, pre-emptive action exercised by the planners of Brazil's coastal towns, and which had been designed to protect local beaches from 


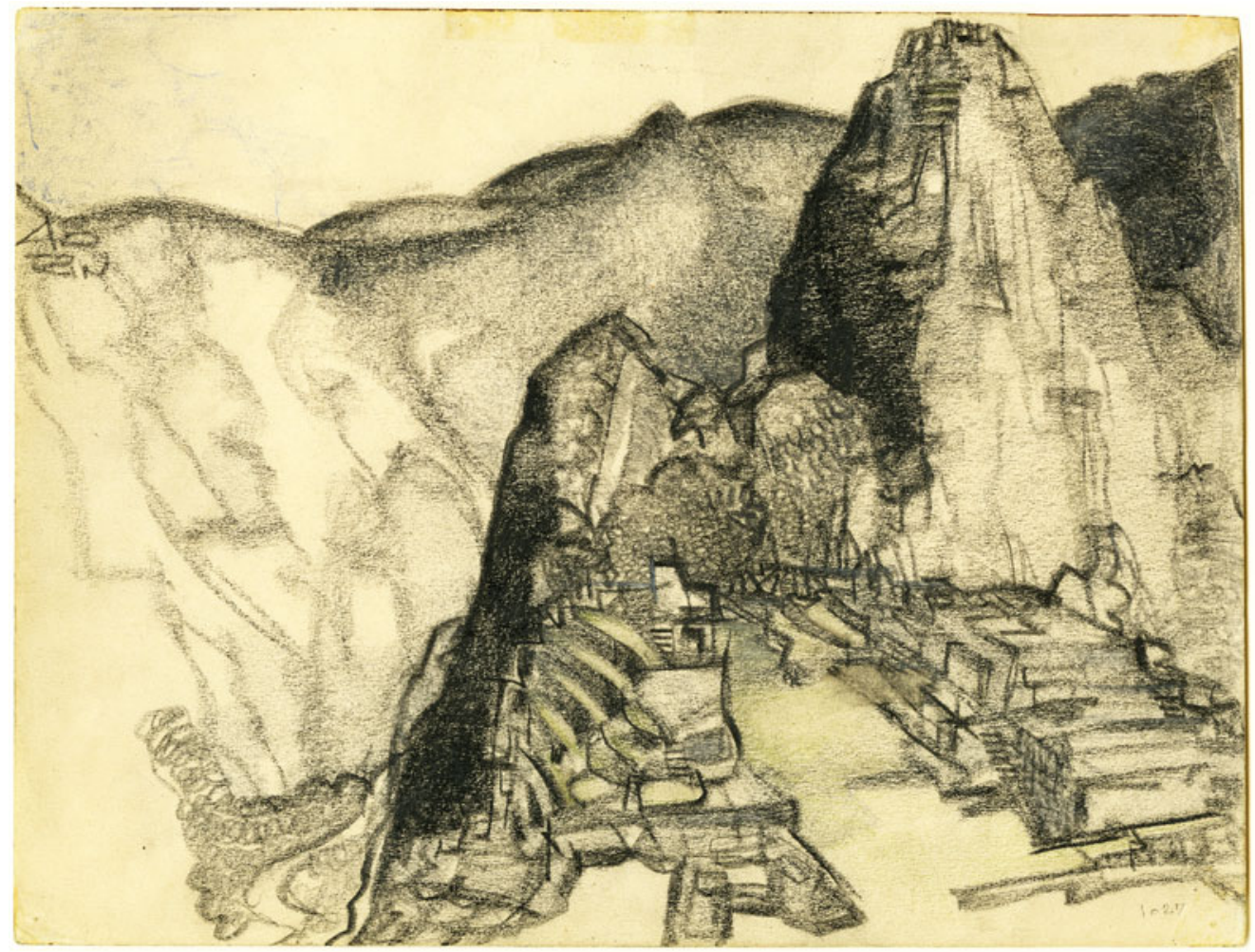

Fig. 13. Richard Neutra, Machu Picchu, 1945 (courtesy Dion Neutra, Architect (C) and Charles E. Young Research Library, UCLA)

'metropolitanization' and over-development. ${ }^{138}$ He also discovered that, in locations as diverse as Monterrey, Buenos Aires and Sao Paulo, the building trades had overcome the inability to import high-tech, mass-produced goods from more developed countries by inventing new manufacturing processes and building infrastructure in ways that were uniquely suited to the local context. ${ }^{139} \mathrm{He}$ observed that:

The current lack of certain materials and equipment has made Mexican, Argentinian, and Brazilian manufacturers inventive; their AVANT-GARDE architects, experimental; their engineers, daring; and their building ordinances (in some cases), very open-minded. Much has been gained; their industry adds considerably to the diversity of world production. ${ }^{140}$

In Buenos Aires, he noted the ways in which the activity and industrial infrastructure of the city's extensive seaport had been integrated successfully with public spaces, a lesson which he encouraged North American architects to learn from their Argentine counterparts. ${ }^{141}$ In Lima, he discovered that, instead of destroying the city's heritage, local architects had used Modern city planning to promote local history by opening 'vistas to 
beautiful old structures like the monastery, Las Nazarenas, which for centuries was hidden from view'.$^{142}$

Neutra visited locations both throughout Latin America and in the Iberian Peninsula: Mexico (1925, 1935, 1937, 1951, 1957, 1962 and 1963), Puerto Rico (1943-45), Argentina (1945), Brazil (1945), Panama (1945), Peru (1945), the Dominican Republic (1945-48), Cuba (1945 and 1956), Guatemala (1951 and 1957), Spain (1954, 1956 and 1969), Venezuela (1955), Colombia (1957) and Portugal (1963-64). He documented these places in at least seventy-nine individual travel sketches. ${ }^{143}$ Moreover, he not only visited them, but he also proposed architectural designs for many sites in these countries, including two unbuilt projects for Caracas (in which he collaborated with the internationally-renowned Spanish engineer Eduardo Torroja), the urban design and planning for the Central Redevelopment of the Port of Caracas (1955-57) 144 and the 'Trebol la Hayada' commercial district (Caracas; $1955-57) \cdot{ }^{145} \mathrm{He}$ also built the sprawling DeShulthess House (1956) in Havana, and the Gonzales-Gorrondona House (1962) in Caracas. ${ }^{146}$ For the latter of these projects, he collaborated with Spanish landscape architect Eduardo Robles Piquer, who was then in exile in Venezuela following the Spanish Civil War, and who, like Neutra had done elsewhere, used a combination of organic and rectilinear forms to extend the house's interior spaces into the surrounding vegetation. ${ }^{147}$

Neutra also studied the cultures of the Europeans, particularly those from Spain, who had colonised Latin America. He readily acknowledged the distinctions between the various regions in Latin America, as well as the ways in which they had diverged culturally and politically from their former colonisers. Yet he was intrigued too by the historical and socio-cultural values that still linked these regions. In a 1954 lecture in Madrid, he stated that, thanks to these still-evident cultural connections, his frequent visits to Latin America had indirectly prepared him for his first visit to Spain in $1954 \cdot{ }^{148}$ He also claimed that:

This visit has been satisfying for me, and [it is] the fulfilment [...] of an old desire. I would like to know more of Spain, but I know it very little, although already before now, from my readings and my professional work, I had a basic knowledge of it. ${ }^{149}$

Immediately following this visit, César Ortiz-Echagüe remarked that Neutra's knowledge about Spanish history, for a foreigner, was surprisingly extensive, and even commented that 'Philip the Second is an old friend in his cultural world. ${ }^{150}$ For Neutra, this first visit did not disappoint. Despite spending only a single week in Spain on this trip, he travelled to Barcelona, Granada, Madrid, Ávila, Segovia and El Escorial, and he experienced at first-hand - with several of Spain's most noteworthy architects as guides - many treasures of Spain's architectural past. With Rafael de la Joya, he toured the prime example of Moorish ${ }^{151}$ architecture, the fortress-palace of the Alhambra in Granada,; 152 with Carlos de Miguel, in Madrid he visited Juan Bautista de Toledo's El Prado palace (by then a museum) and watched a bullfight, which his wife Dione described as 'a most interesting experience', 153 and with Ortiz-Echagüe and Miguel Fisac, he visited the city walls of Ávila, the Roman aqueduct in Segovia and the monastery-palace at El Escorial, which interested him so much that he requested to visit it again a few days later with Modesto López Otero (the director of the School of Architecture in Madrid). ${ }^{154}$ Among the famous buildings forming the complex at El 
Escorial, he was most captivated by the Basilica of San Lorenzo, and Ortiz-Echagüe later recounted that, for Neutra, 'this church was one of the best in the world, if not the very best among those that he had seen.' 155

After returning home to Los Angeles, he wrote to Fisac that 'we loved your country and certainly hope we may see you all again. ${ }^{156}$ During this visit, Neutra had explored the rich tradition that, for centuries, had produced the buildings and cities that had inspired much of the historic architecture he had been studying for years in California and Latin America. Despite the astonishing number of important sites he toured, he was still disappointed that the brevity of this first visit had not afforded him the opportunity to develop an intimate understanding of Spanish architecture and culture, taking the view that 'first you need to become acquainted with the people, [...] absorb their way of thinking and feeling, and then try to comprehend their architecture.' ${ }^{\prime 157}$

However, a new opportunity was not long in coming. In 1956, a team of over forty Spanish architects and engineers invited Neutra to take the lead in designing prototype housing units (unbuilt) for US Air Force personnel stationed in four locations in Spain. ${ }^{158}$ Apparently, his Spanish collaborators had selected Neutra to head the team for two reasons. First, they had hoped that his name would improve their chances of success with the competition's jury. Secondly, they recognised that his interest in their traditions transcended that of an erudite tourist, having seen evidence that he had already successfully merged elements of Modern architecture with the vernacular architecture of California, Latin America and Spain, in his buildings from previous decades. Such amalgamations included the patios at the Corona Avenue School (Los Angeles, 1935), the Kaufmann Desert House (Palm Springs, 1946), the passive ventilation strategies of the Tremaine House (Montecito, 1948), the sun-shading devices of the Northwestern Mutual Fire Association Building (Los Angeles, 1950) and the 'spacious porch' of the Eagle Rock Park Clubhouse (Los Angeles, 1953). ${ }^{159}$ For Neutra, it was a rare opportunity to acquaint himself with the Spanish people, and 'to try to comprehend their architecture', and integrate Spanish cultural values with his own Modern ideas. ${ }^{160}$

\section{ADAPTING STRATEGIES FROM THE ARCHITECTURE OF LATIN AMERICA AND SPAIN}

In the September 1965 issue of the Madrid journal Arquitectura, Francisco Prieto Moreno, the leading expert on Spain's Moorish architecture and chief conservation architect for the Alhambra, published an article entitled 'Coincidencias de Neutra con las arquitecturas orientales' ('Correspondences between Neutra and Oriental Architectures'). ${ }^{161}$ There, he identified remarkable similarities between, on the one hand, the Alhambra, the gardens of the Generalife, and the typical Andalusian country house, and, on the other, Neutra's works, such as the Hafley-Moore Houses (Long Beach, 1953), the Kronish House (Beverly Hills, 1955) and the Slavin House (Santa Barbara, 1956). He attributed such 'correspondences' to a similar sense of human scale and to the fact that both Neutra and Spain's Moorish architects had adapted architecture to the natural condition of the site. ${ }^{162}$ In both Neutra's work and Moorish architecture, he also discovered an analogous use of vegetation, and translucent privacy screens and features exploiting sun and shade patterns, as well as the seamless connection of interior and exterior spaces. ${ }^{163}$ For Prieto Moreno, Neutra's attempts to reconnect the human 
being to nature, which had been initially inspired by his reading of Wundt, also paralleled the 'vegetative ideal' as defined by the Spanish philosopher José Ortega y Gasset (1883-1955), which Prieto Moreno described as a rejection of perfect geometry (and rules involving the Golden Section) as determinants of architectural form, in favour of an architecture that used natural elements and organic shapes to stimulate the senses. ${ }^{164}$

Perhaps because of the high level of celebrity that Neutra, by 1965, had gained in Spain and Latin America, Prieto Moreno side-stepped any implication that Neutra's use of such concepts in his own work might, in any way, have been actually inspired by Spain's Moorish architecture. However, these supposed correspondences between Neutra's work and vernacular architecture of Latin America and Spain were no mere coincidence, because, instead, they had resulted from his study of these regions. The Spaniard Fernando Higueras remembered that, during his visit to the Escuela Técnica Superior de Arquitectura in Madrid in 1954, Neutra had publicly acknowledged that 'the true spatial essence of my work is extracted from the architectural heritage of Spain, especially [from] the Alhambra of Granada. ${ }^{165}$ Likewise, in his 1954 book Life and Human Habitat, he compared the shared green spaces of his 1942 Channel Heights project and his unbuilt Elysian Park Heights project (Los Angeles, 1949-59) with the plazas and patios that he had visited and sketched during his travels in Mexico, Peru and Cuba. ${ }^{166}$

From his studies of buildings in the American Southwest, Latin America and Spain, Neutra had adapted three architectural strategies to deal with life in warm climates: sun-control devices, 'sub-soffit ventilation' in which the exterior wall stops short of the roof deck to allow continuous air exchange, and the interior patio as a means of uniting interior and exterior spaces. In a 1946 article in Progressive Architecture, he claimed that, since the early 1930 s, he had been experimenting with shading strategies, although, by his own admission, he 'did not pursue [these] ideas to an ultimate conclusion'. ${ }^{167}$ The two-year project in Puerto Rico (1943-45) and his 1945 tour through Latin America had then given him the opportunity to study the elegant, efficient sun-control devices that had been used on Modern buildings in Buenos Aires, Sao Paulo, Rio de Janeiro and Pampulho. The movable vertical louvres, designed and patented by the Argentinian architect and city planner Julio Villalobos, had particularly interested him, and he used his article to promote Villalobos's sun-control devices to North American architects. ${ }^{168} \mathrm{He}$ also noted that this device had been used widely throughout Latin America, such as by Jorge Ferrari Hardoy and Juan Kurchen in Argentina, and Oscar Niemeyer and Eudardo Agusto Kneese de Mello in Brazil. Neutra also highlighted the 'glass louvers operated by concealed cables, roll shutters and mechanized, custombuilt metal sash and doors' designed by Warchavchik and Wladimir Acosta for buildings in Brazil. ${ }^{169} \mathrm{He}$ himself then began to incorporate sun-shading louvres into his own projects. Their earliest applications are in his Kaufmann Desert House (1946), the Northwestern Mutual Fire Association building (1950; Fig. 14) and the second VDL Research House (1966; Fig. 15), which all postdate the studies he conducted of such devices during his visits to Puerto Rico and other parts of Latin America between 1930 and 1945 .

According to Dion Neutra, the two-year experience in Puerto Rico was pivotal for his father. There, Neutra had learned, for example, the need for adequate consideration of trade-winds and their implications for architectural design, as well as a correct response 


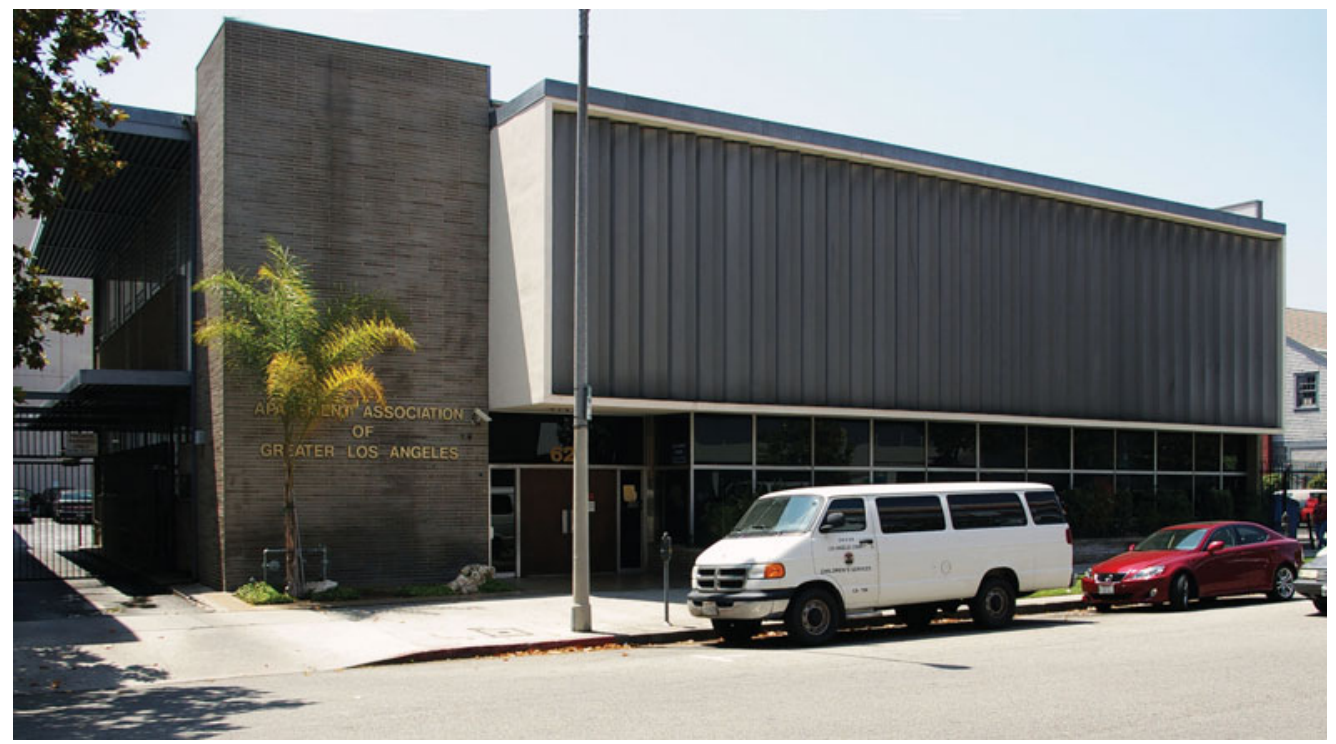

Fig. 14. Los Angeles, Richard Neutra's Northwestern Mutual Fire Association, showing sun-shading devices (author's photograph, 2009)

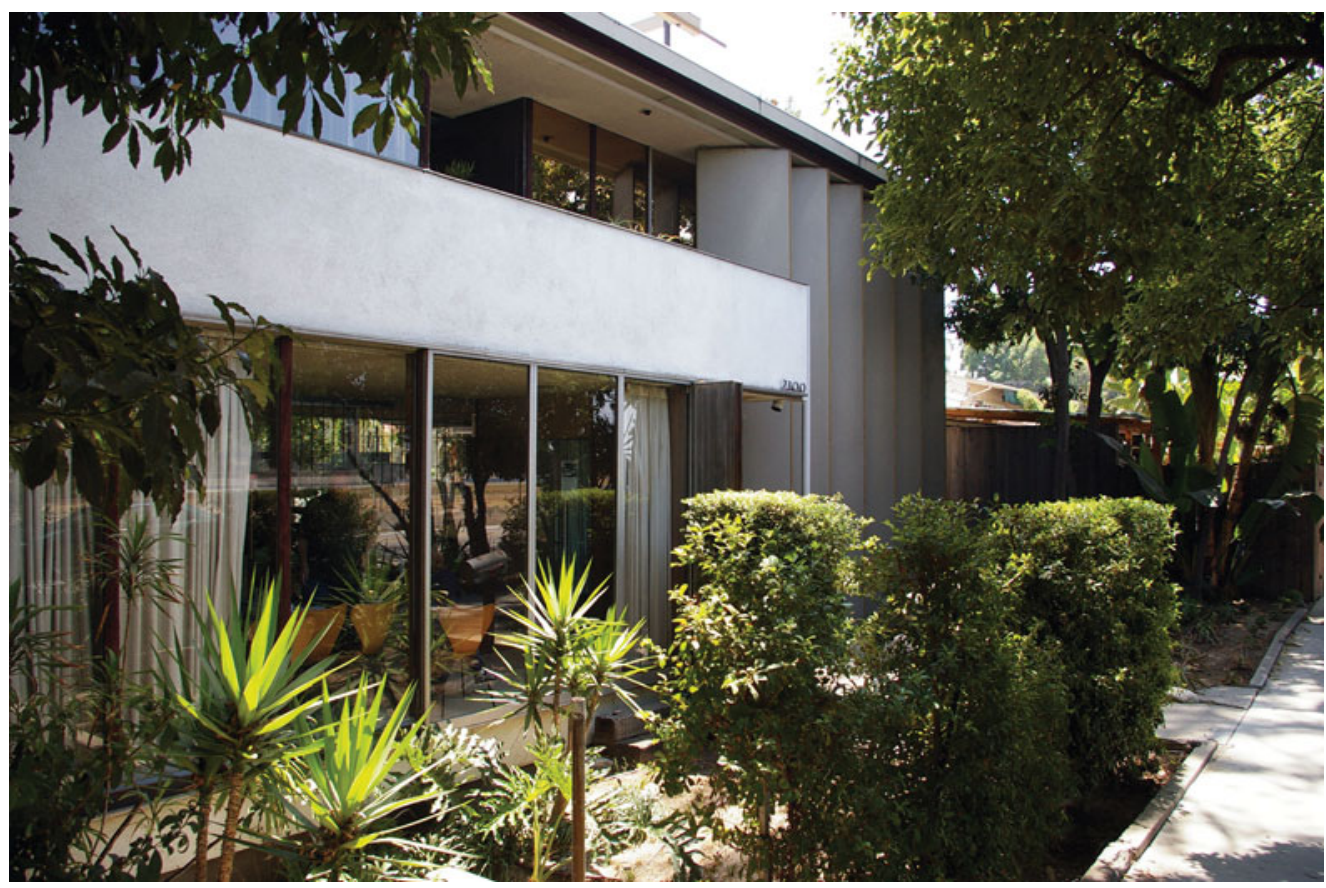

Fig. 15. Los Angeles, Richard Neutra's VDL Research House II, showing vertical sun-shading devices at far right (author's photograph, 2009) 


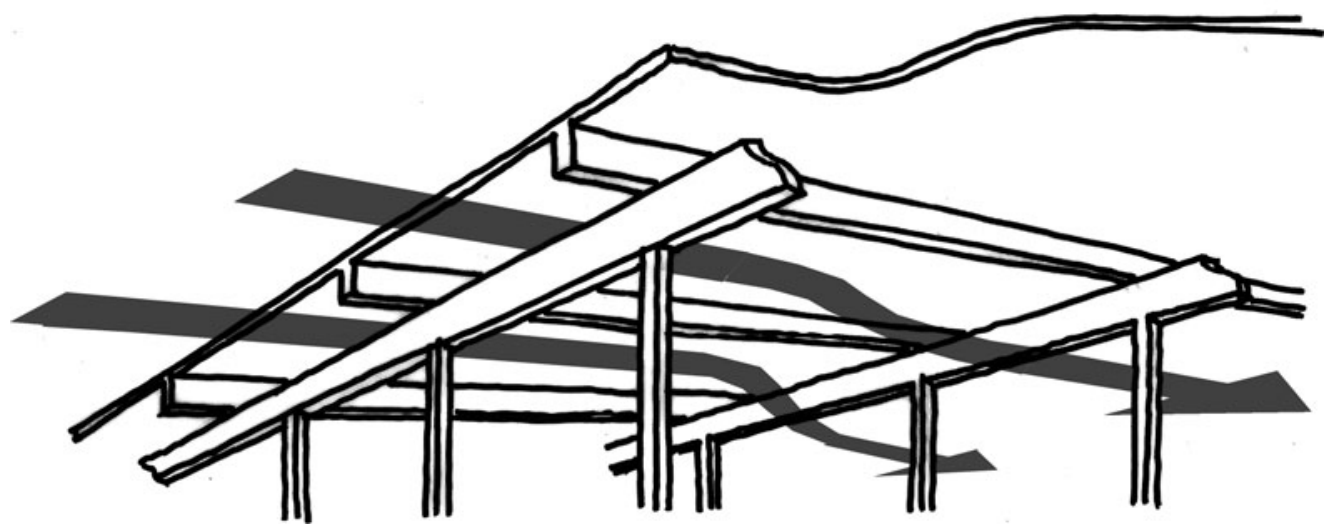

Fig. 16. Richard Neutra, sketch of the continuous soffit vents he designed for buildings in Puerto Rico, 1944 (as redrawn by author after the original)

to other 'natural conditions', such as topography, orientation, vegetation, climate and sun shading. ${ }^{170} \mathrm{He}$ had already used cross-ventilation as a cooling strategy prior to his work in Puerto Rico, in projects such as the 1935 Corona Avenue School; but in Puerto Rico he refined this strategy. Inspired by local climate-responsive techniques of natural ventilation that take advantage of 'the prevailing breezes, which are such a boon to the island', he developed what he referred to as 'sub-soffit ventilation' (Fig. 16), in which the voids between the roof's concrete T-joists are left uncapped at both ends, allowing warm air to be drawn quickly out of the interior spaces by prevailing breezes. ${ }^{171}$ He replicated this system in his Tremaine House in Montecito, California (1948), although this time filling the voids between the concrete T-joists with openable glazing. ${ }^{172} \mathrm{He}$ believed that the strategies for tropical climates he had developed during his time in Puerto Rico were so appropriate for sites in warm humid zones of Latin America that, in his 1948 book Architecture for Social Concern, he promoted the results of his work on the island as a guide for Modern construction throughout these Latin American regions. ${ }^{173}$

Neutra was also inspired by the uses of fully-enclosed interior patios, which he discovered during his travels in California, Latin America and Spain. ${ }^{174}$ However, he was not the only architect of central European origin who, in the 1920s and 1930s, exploited the patio as a means of providing exposure to sunlight and fresh air, but without compromising the privacy of the single-family home; Mies van der Rohe's courtyard houses of the early 1930s and Walter Gropius's own house (Lincoln, Massachusetts, 1938), all organise interior spaces around fully-enclosed exterior patios. ${ }^{175}$ In a 1956 article published in House and Home, Neutra acknowledged that the patio had been used commonly in other parts of the world, such as Greece, Rome and Japan, and his sketch diaries indicate that his interest in patios and courtyards had begun long before his initial personal contact with the historic architecture and warm climates of California, Latin America and Spain. ${ }^{176}$ Not surprisingly, Spanishspeaking architects such as Barragán and Josep Lluis Sert had also been inspired by 
Fig. 17. Richard Neutra, VDL Research House I, plan showing the house as originally designed, 1932 Los Angeles (author's drawing)

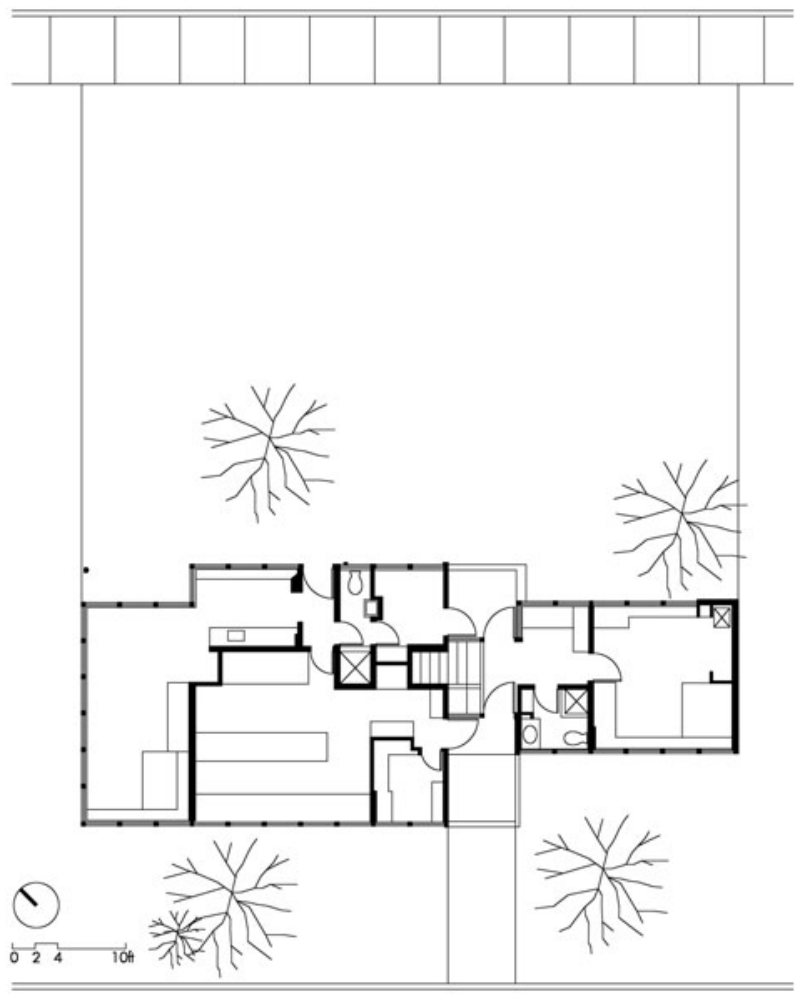

the patios of their own heritages. However, Neutra's central European origin sets him apart in regard to his apparent preference for the patios of Spain and Latin America. In his House and Home article, his search for ancient sources of this spatial prototype is presented as being focused most frequently on civilisations of Spanish or Latin American heritage, such as Altamira (located in Cantabria in northern Spain) and the Incas. ${ }^{177}$ Moreover, while Neutra's patios were, indeed, effective technical solutions for the Mediterranean climate of coastal Southern California, as well as the deserts of the American Southwest, they were also deft interpretations, as McCoy has proposed, of the vernacular forms of Spain and Latin America. For example, she has suggested that the interior patios in Neutra's 1961 Painted Desert and Petrified Forest Visitors Center were inspired by the quadrangle of the Mayan Nunnery at Uxmal (Mexico), which Neutra may have visited in the late 1930s. ${ }^{178}$

The fully-enclosed patio did not emerge as a common theme in Neutra's built work until after his arrival in Los Angeles. The 1923 houses in the Zehlendorf district in Berlin, designed while Neutra was employed by Mendelsohn, are indeed arranged around a loosely-defined exterior space, but this space is not as clearly defined as the fully-enclosed exterior patio that would come to mark his later work in California. ${ }^{179}$ In 1927, however, only two years after arriving in Los Angeles, he designed three projects with fully-enclosed interior patios. First, in his unbuilt schemes for houses on 


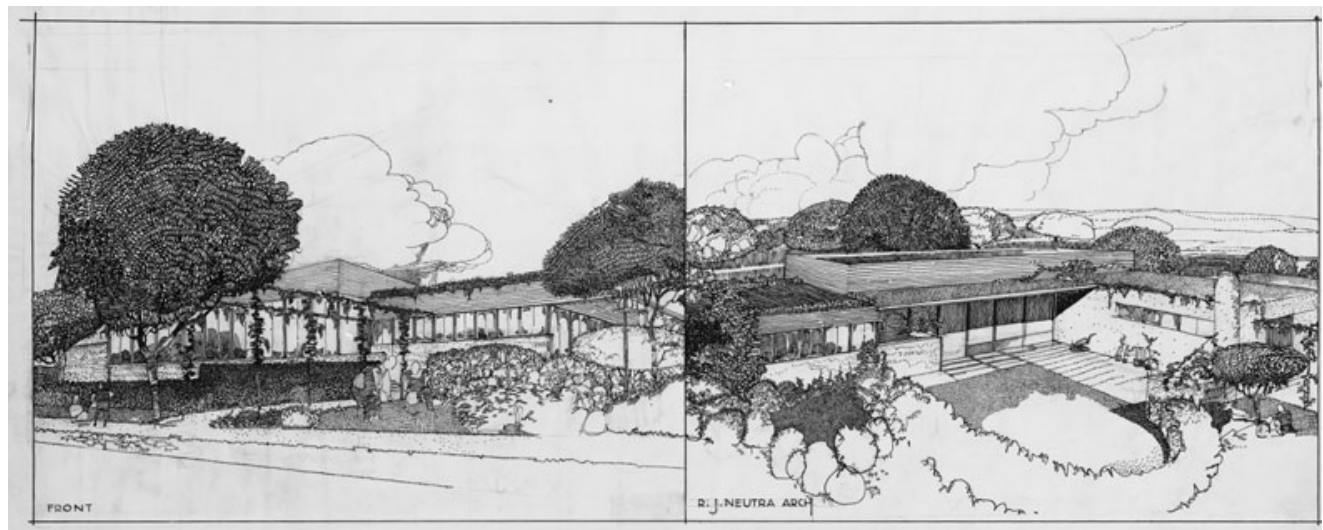

Fig. 18. Richard Neutra, sketch of the Agricultural Workers Cooperative Housing (c. mid-193os; unbuilt) at Riverside, California (courtesy Dion Neutra, Architect (C) and Charles E. Young Research Library,

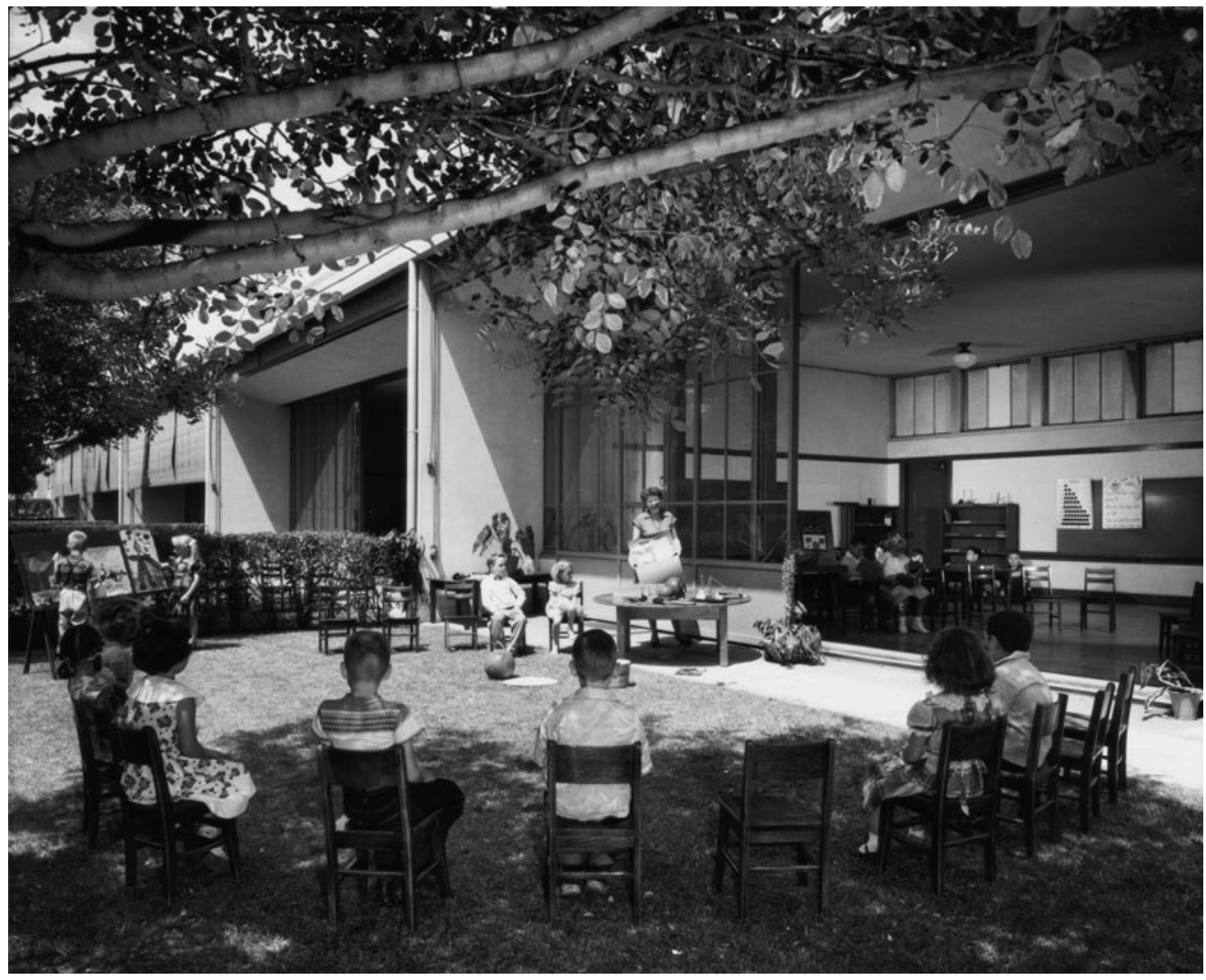

Fig. 19. Los Angeles, Richard Neutra's Corona Avenue School, showing the exterior patio in use (photograph by Julius Shulman; courtesy Dion Neutra, Architect (; and (C) J. Paul Getty Trust) 


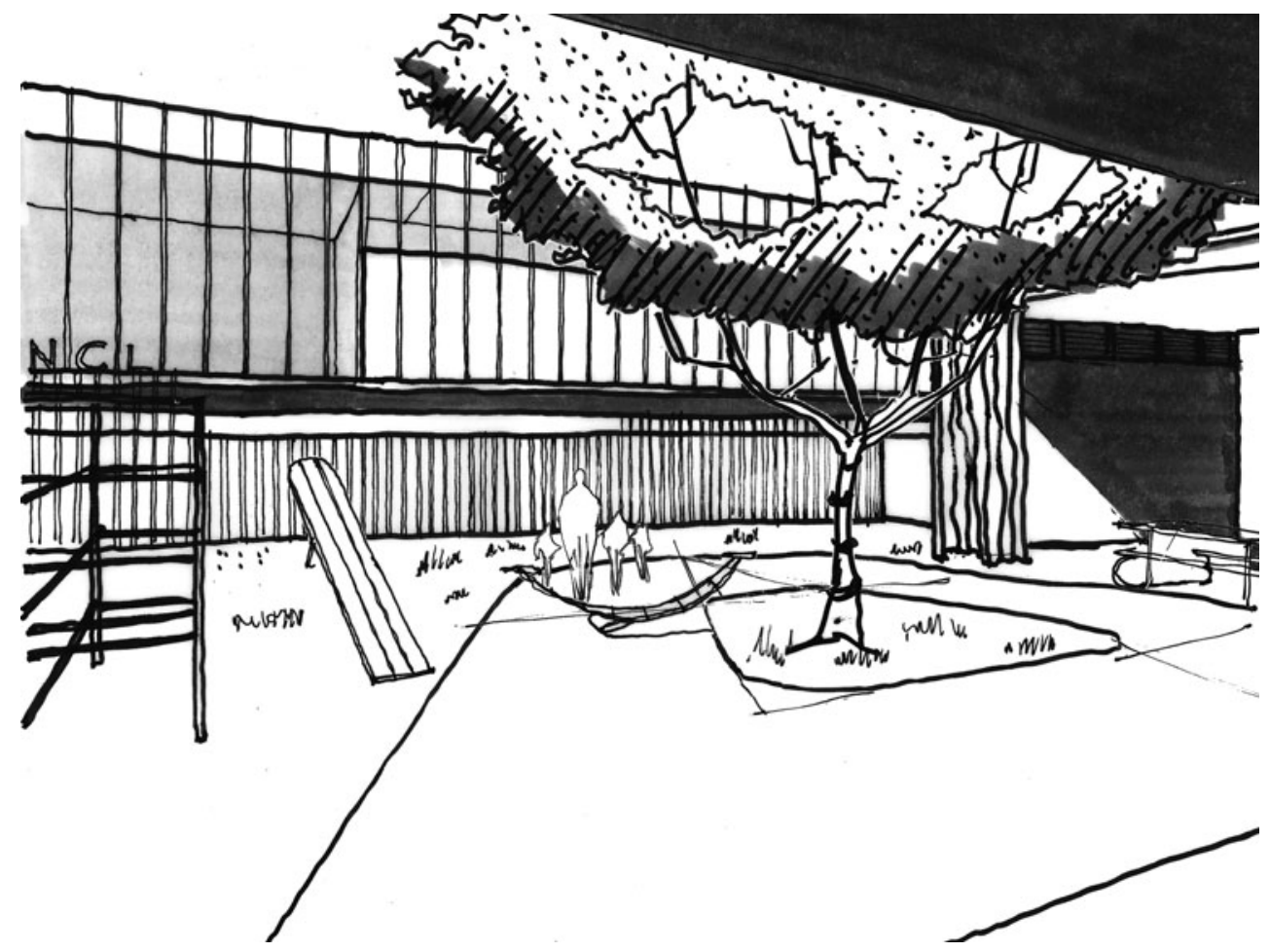

Fig. 20. Los Angeles, Richard Neutra's National Charity League, showing interior patio (author's drawing)

sites in and around Santa Monica, which he designed in the Spanish Colonial style, the dining room, living room and breakfast room open onto a small colonnaded patio. ${ }^{180}$ Second, his first built project in Southern California, the 1927 Jardinette Apartment building, is likewise organised around a tight patio, defined on three sides by the building's façades, and on the fourth by a half-height garden wall. ${ }^{181}$ Third, similar to the Jardinette, his unbuilt Ambrose Apartment building, which he designed in 1927 for another site in Los Angeles, is organised around a 'garden court'. ${ }^{182}$

Despite its ample natural light and ventilation, the 1932 VDL Research House (Fig. 17) had been more stylistically akin, in its original form, to the International-Style white boxes of the 1927 Weissenhofsiedlung than to Neutra's mature works of the 1940s and 1950s, which seamlessly connect interior and exterior spaces. Nevertheless, a series of buildings Neutra designed subsequently, and before the addition of the VDL Garden House in 1939, reveal an increasing incorporation of interior-exterior spaces, all designed as outdoor rooms reminiscent of Spanish and Latin American patios.

Following the VDL Research House, Neutra's little-known, and once more unbuilt, project of the mid-1930s for agricultural workers' co-operative housing in Riverside, California (Fig. 18) constitutes one of his earliest attempts to use the patio in a small-scale 


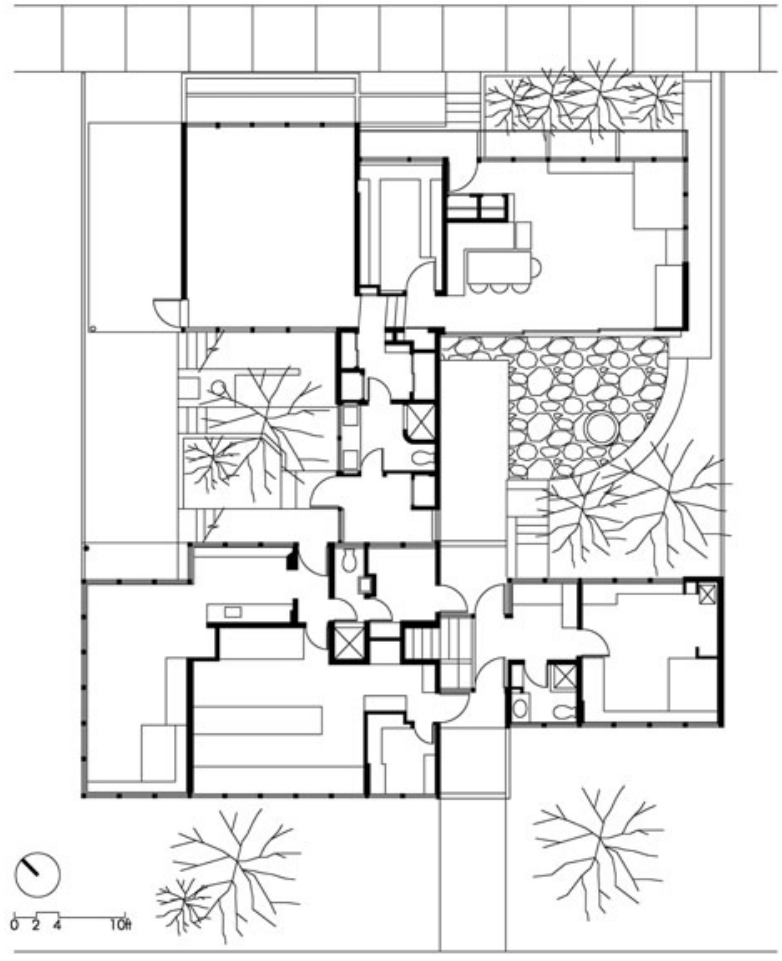

Fig. 21. Los Angeles, Richard Neutra's addition of the garden house to the VDL Research House I (author's drawing)

residence as a means of expanding interior space towards the exterior. ${ }^{183}$ Although the project's programmatic and budgetary restrictions did not allow for large interior living spaces, Neutra compensated by incorporating exterior living spaces, which he designed as comfortable outdoor extensions of the interior rooms. With large sliding glass walls, which he had used previously in his Beard House in Altadena (1934), he joined the rows of dormitory rooms to outdoor patios that were completely enclosed by the L-shaped building's two wings, and by a curving hedge to provide privacy. As in Latin American and Spanish patios, these outdoor spaces were shaded by roof overhangs, trees and vegetated pergolas, and they also featured a combination of lawn and paving in order to provide the flexibility to accommodate a variety of activities. ${ }^{184}$

Neutra again used the vernacular Spanish and Latin American patio in his 1935 Corona Avenue School (Fig. 19). By using sliding glass walls, he expanded the interior space of each classroom into an adjacent outdoor patio, so that educational activities could move fluidly from inside to outside, and in order to improve student learning and health. ${ }^{185}$ Obregón Santacilia recognised this innovative use of the patio in his 1939 book El maquinismo, la vida y la arquitectura, and he recommended it to his readers as an appropriate feature to incorporate into Modern schools in Mexico. ${ }^{186}$ Throughout the following years, this notion of indoor/outdoor education became a 
hallmark of Neutra's school designs. It re-appeared in his children's centre for the National Charity League in Los Angeles (1955) (Fig. 20), in his 1956 design for schools for the US Air Force Bases in Spain, in his UCLA Elementary School (Los Angeles, 1957), in his Richard J. Neutra School at the Naval Air Base in Lemoore (1961) and in the Palos Verdes High School (Los Angeles, 1961). ${ }^{187}$

Neutra's appropriation of the patio in his own work evidently crystallised in the 1939 addition to the original VDL Research House. Dion Neutra remembers that when Neutra designed the first VDL Research house (1931-32) he did not plan the future addition of the garden house. ${ }^{188}$ The intervening years between the two projects therefore constitute an evolution in his work: from the pure geometry of the Modernist white box to the diaphanous interior/exterior spaces that characterise his later works. He located the single-storey VDL Garden House along the rear property line, in accordance with what he described as 'the old Spanish custom' of building up to the property lines, in order to carve out an interior patio. ${ }^{189} \mathrm{He}$ believed that this technique of maximizing available building space had been perfected

on the Island of Capri and in the mountain villages of Spain centuries ago. There a series of patios would supplement skimpy indoor floor areas and provide outdoor rooms separated from the neighbors by walls that assured privacy to each family. A contemporary house can solve the small lot problem in the same way. ${ }^{190}$

The VDL Garden House (Fig. 21) was connected to the original house through a sequence of single-storey rooms that subdivided the property into two patios, one for service functions and the other for family life. The larger of these patios also functioned as the primary access to the interior living room of the Garden House, and it served as an additional exterior living space too. ${ }^{191}$ By means of another sliding glass wall, the new interior living room was then seamlessly joined to the exterior patio (Fig. 22). This patio was designed as a physical and spiritual haven: 'A patio is very different from a mere terrace. A house surrounded by a garden is one thing, but a house that has an articulated outer extension of the living area is another thing for body and soul. ${ }^{192}$ Barragán, who enjoyed a weeklong stay in the VDL Research House, remembered its patio as the most comfortable space of the house, thanks to its privacy and the inclusion of vegetation. ${ }^{193}$

In the years following the completion of the VDL Garden House, the fully-enclosed patio continued to appear in Neutra's works. For the 1953 Hafley-Moore houses, Neutra chose to unite these two separate residences with a shared, L-shaped patio and a pergola, and he used large expanses of glass to link the patio to several of the homes' interior spaces. In his 1956 House and Home article he used the exterior space between the two houses to illustrate the ways in which the patio can be a shared space, while maintaining the requisite privacy of a single-family dwelling. ${ }^{194}$ For Prieto Moreno, the patio of these twin houses was essentially 'Andalusian' because of Neutra's skilful use of vegetation to create effects of dappled light and shifting shadows. This feature, in his view, made this space 'identical' to the typical Andalusian carmen (walled garden): ${ }^{195}$

The fabric of pergolas, closed and open patios, exterior garden, and swimming pool, with their extremely varied internal environments, recalls, in a great way, the design of the carmen of Granada, charged with Muslim influences. ${ }^{196}$ 


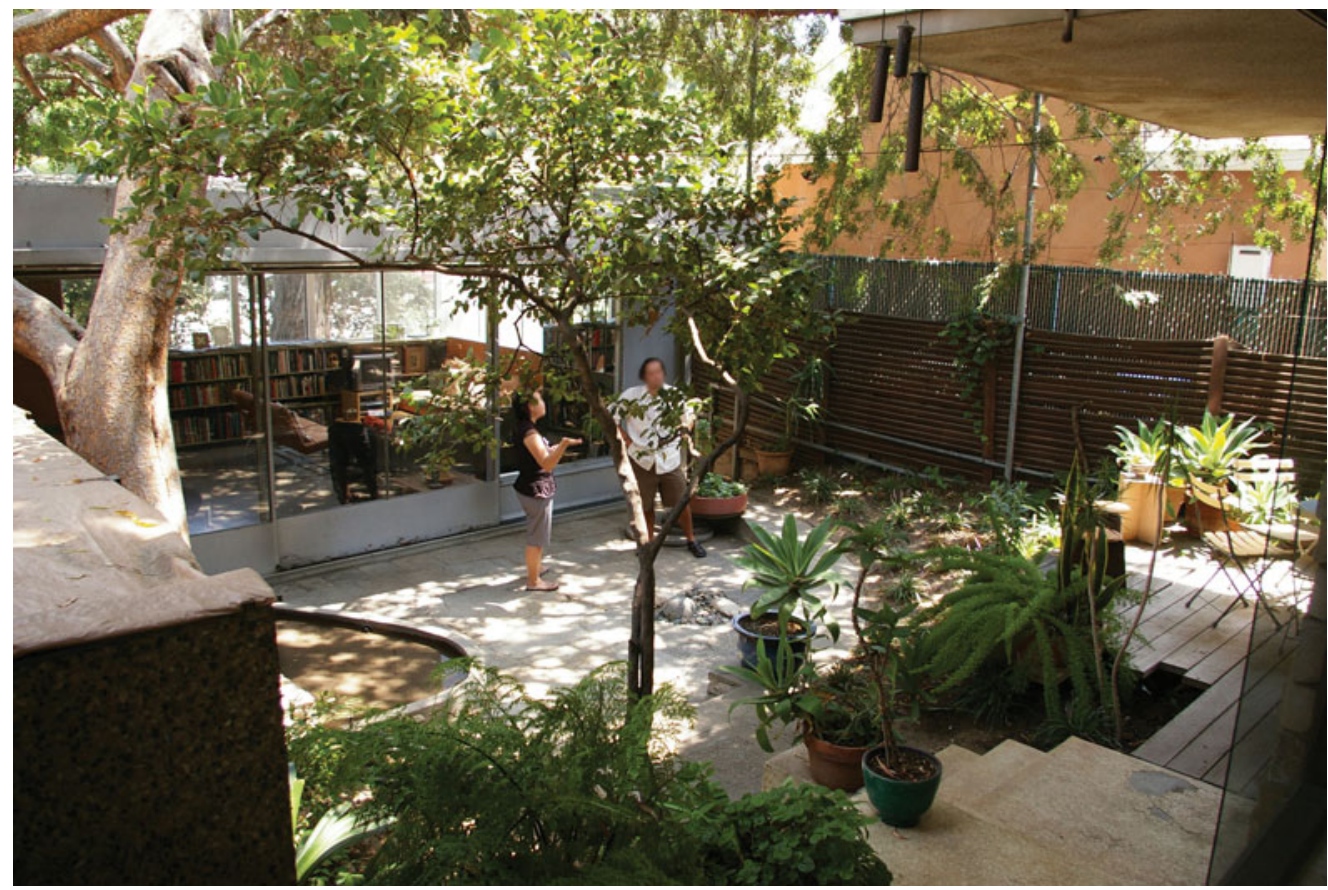

Fig. 22. Los Angeles, Richard Neutra's VDL Research House II, showing the 1939 Garden House in the background and the interior patio as rebuilt in 1966 after the original was destroyed by fire in 1963

(author's photograph, 2009)

He also stated that, in the case of Neutra's 1955 Kronish House,

the living spaces are centred in a way similar to [that of] the living spaces in the [Moorish] house, with perspectives in various directions towards interior patios, and towards exterior gardens. ${ }^{197}$

Other Spanish architects were similarly impressed by Neutra's use of the patio, which they also believed to have been derived from their own architectural tradition. In their introduction to Neutra's film The Ideas of Richard Neutra, which premiered in Madrid in 1969, the architects Francisco Zamora and Rafael Alfonso highlighted Neutra's use of the patio as a means of uniting interior and exterior spaces; but they also noted that Neutra's ability to fuse his own ideas of Modern architecture with a spatial configuration that he had learned from their own tradition had ultimately resulted in the creation of an entirely new type of patio. ${ }^{198}$

\section{CONCLUSION}

In his 'search for the southland', Richard Neutra had learned from a diverse array of global cultures, yet, as this article has explored, a principal source was the shared heritage and local idiosyncrasies of the American Southwest, Latin America and Spain. Years before he emigrated to the United States, he had already demonstrated a keen 
interest in California, Mexico and other parts of Latin America, which is plainly evident as early as 1914 in his correspondence with Rudolph Schindler. Experts on these regions, such as César Ortiz-Echagüe, Gregori Warchavchik and Irving Myers, remarked that, even before visiting them, Neutra had already studied the architecture of these regions, as well as their diverse climates, geographies, cultural idiosyncrasies, politics, traditions and histories.

Neutra's study of these regions, moreover, was more extensive than that of other architects practising in North America, such as Frank Lloyd Wright, Irving Gill, Rudolph Schindler and Gordon Kaufmann, and it eventually had a profound effect on his own professional work. It is well-known that, during the first several years following his arrival in Los Angeles, he had refined his modernist aesthetic and had produced several of his most internationally-acclaimed, avant-garde projects, such as the 1927 Jardinette Apartments, the 1927-29 Lovell Health House and the original portion of the 1932 VDL Research House. This article, however, has demonstrated that at the same time as he was designing these examples of Modern architecture he was also experimenting with - and sometimes even copying - the forms of the Spanish Colonial style, this being evident in such projects as the 1927 Santa Monica Houses and the 1928 Richmond Civic Centre. Initially, these two trends in his work had seemed to be at odds with each other but, even as early as 1926, he began to utilise sympathetic juxtapositions of forms, as seen in the Modernist gymnasium addition to the Baum house, a Spanish Colonial quinta.

Over the course of his first decade in Los Angeles, following the lead of Wright, Schindler, Gill and Kaufmann, Neutra eventually transcended sympathetic juxtapositions of forms and successfully achieved a synthesis of Modern ideas and the local architectural traditions of California and Latin America, a trait he had appreciated in the work of Mexican architects such as Obregón Santacilia and Juan O'Gorman. At the Lovell Health House, he adapted the Californian sleeping porch for use in a home focused on Modern standards of health, hygiene and exercise. The fully-enclosed patio he had seen on his early tours through California (in the mid-1920s) and his first visit to Mexico (in 1925) emerged as a frequent theme in his work, beginning with the fully-enclosed patio that appeared in the 1927 Jardinette Apartments, just two years after his arrival in Los Angeles. In the 1935 Corona Avenue School, he adapted the open-air patio to suit modern pedagogical models. In the 1937 von Sternberg House (Los Angeles) and the 1939 addition of the Garden House to the VDL Research House, he then appropriated the patio in order to promote the Modern ideal of life en plein air, and to realise fully the fluid connection between interior and exterior space that he had sought ever since his first readings of Wundt's Principles of Physiological Psychology. Even his later works, such as the 1961 Petrified Forest and Painted Desert Visitor's Center, openly referenced the forms of indigenous pueblos of the American Southwest.

Neutra's tours through Central and South America also offered him the opportunity to research architectural strategies for responding to the unique climatic and cultural conditions of subtropical locations. While working in Puerto Rico in the early 1940 s he experimented with the 'spacious porch' in the prototype health centres that he designed for locations across the island,199 the 1953 Eagle Rock Park Clubhouse features similar porches, which Neutra conceived as outdoor extensions of indoor spaces. In Puerto Rico, he had also developed a cooling strategy that he called 'sub-soffit 
ventilation', and which he later used in the 1948 Tremaine House. Prior to his 1945 tour of Latin America he had experimented with sun-shading devices, yet, by his own admission, it was only during this tour that he learned the proper use and application of such devices, which he subsequently exploited in projects such as the 1946 Kaufmann House, the 1950 Northwestern Mutual Fire Association building and the 1966 reconstruction of the VDL Research House.

The fact that Neutra's 'search for the southland' had led him to study the architecture and cultures of the American Southwest, Latin America and Spain, and to apply these lessons in his own work, was plainly evident to the architects who were native to or made their own homes in these regions. The Mexican architects Carlos Obregón Santacilia and Luis Barragán, whose own work had represented a fusion of Mexican tradition and Modern ideas, also discovered evidence of this fusion in Neutra's work. Gregori Warchavchik described Neutra as an open-minded artist whose sketchbook reflected a deep understanding of the cultures he visited on his travels through Latin America. Spanish architects also appreciated Neutra's study of their own history and tradition; Francisco Prieto Moreno recognised deep similarities between Neutra's work and Moorish architecture; César Ortiz-Echagüe remarked that, for a foreigner, Neutra was unusually familiar with Spanish history and tradition; and, in 1956, a team of Spanish architects selected Neutra to lead their design of housing for the US Air Force Bases in Spain, in part because he had demonstrated to them that his version of Modern architecture was inherently compatible with Spanish sensibilities.

\section{ACKNOWLEDGEMENTS}

For their help in the preparation and publication of this article, I would like to acknowledge the contributions made by the following people. The idea to investigate Neutra's interest in the architecture of California, Latin America and Spain originated in 2009 from my conversations with my doctoral dissertation chair, Dr Miguel Alonso del Val. Thomas Hines and Dion Neutra have also provided critical insight into the subject. I thank the blind referee and Judi Loach for their critique of the ideas and text. I also thank Dion Neutra, the J. Paul Getty Trust, the Getty Research Institute, Thomas Hines and the University of Southern Illinois Press, for graciously granting me permission to publish several of these images, and I thank Simon Elliott and the staff of the Department of Special Collections, Charles E. Young Research Library, UCLA, for their assistance in locating and scanning some of them. Finally, I thank the College of Architecture and Environmental Design and the University Libraries at Kent State University, which provided funding for copyright and reproduction fees.

All foreign-language quotations are the author's translations unless otherwise stated.

\section{BIOGRAPHY}

Dr Brett Tippey is Program Coordinator for Architectural Studies and Assistant Professor in the College of Architecture and Environmental Design at Kent State University (Ohio). He teaches design studios and courses in the history of modern architecture and structural typology. He holds a Bachelor of Architecture (2001) from Ball State University, a Master of Architectural Design (2005) from the University of Navarra (Spain) and a Doctorate in the history of modern Spanish architecture (2011) from the University of Navarra. His research and publications focus on the work of Richard Neutra and the history of modern architecture in Spain; his doctoral dissertation analysed Neutra's involvement in Spain in the 1950 s and 1960s. Dr Tippey is also a registered architect (Indiana) and he has 
completed professional architectural projects in the USA, Spain, Portugal, Peru, Libya, Egypt, Jordan and Lebanon, including public libraries, conference/retreat centres, healthcare facilities, K-12 schools and institutes of higher education. btippey@kent.edu

\begin{abstract}
During the twentieth century, diverse cultures from around the globe served as vital sources for architects who attempted to merge Modernist ideas with traditional values. Richard Neutra (1892-1970) absorbed ideas from Japan, the American Middle West and his own native Austria, and eventually his study of these regions deeply affected his work. By analysing archival sources and period publications, this article reveals that even before emigrating to the United States (1923), and throughout his career, the cultures of California, Latin America and Spain were also sources for Neutra's work. He travelled extensively throughout these regions, he researched their local customs and architecture and he deftly and purposefully incorporated vernacular elements, such as sun-shading devices, ventilation strategies and interior patios, into his own work. For his Latin American and Spanish colleagues, his work exemplified a successful fusion between their own traditions and Modernist principles.
\end{abstract}

\title{
NOTES
}

1 The phrase used is 'ciudadano del planeta'; see Richard Neutra, La arquitectura como factor humano (Madrid, 1954), p. 5. This article is a transcription of the keynote address Neutra gave, under the same title, at the Instituto de la Construcción y del Cemento in Madrid on 24 November 1954.

2 Gregory Warchavchik, 'Introduction', in Richard Neutra, Architecture of Social Concern in Regions of Mild Climate (Sao Paulo, 1948), pp. 10-34 (p. 28). This volume uses the Anglicised version of Warchavchik's given name, Gregori.

3 Thomas Hines, Richard Neutra and the Search for Modern Architecture (New York, 1982), p. 15.

4 Ibid., p. 25.

5 Arthur Drexler and Thomas Hines, The Architecture of Richard Neutra: From International Style to California Modern (New York, 1982), p. 23.

6 In a letter dated 12 March 1921, Schindler informed Neutra that Wright was currently in Japan, and that he might invite Neutra to join him there as a collaborator. Neutra was open to this possibility, and it appears that Wright was indeed interested; ultimately, however, Wright was unable to commit to inviting Neutra to Japan, presumably due to uncertainty in his workflow. See Esther McCoy, Vienna to Los Angeles: Two Journeys (Santa Monica, 1979), pp. 134-35.

7 Neutra kept drawings (probably not travel sketches) of many buildings designed by Japanese architects: Los Angeles, Richard and Dion Neutra Papers, 1925-70, Collection 1179, Special Collections, Charles E. Young Research Library, University of California, Los Angeles, Oversize Folder 2016. Hereinafter, this source will be cited as 'UCLA', followed by the item's box number and folder number. The drawings are of a weather station in Kyushu designed by S. Horikuti (drawing undated), an apartment building in Shimodera (drawing undated), JAL office building in Tokyo (drawing undated but perhaps a later insertion since this building may have been constructed much later than 1930) and Osaka Central Wholesale Market built in 1931 (drawing undated), plus a map of Tokyo City (drawing dated 1930) and a map of Osaka Municipal Retail Market (built in 1927).

8 For travel sketches that Neutra drew while in Japan in 1930, see UCLA, Box 2, Folders 1-19, and UCLA, Box 1287, Folders 1-5. Neutra also made travel sketches of sites in Japan on two subsequent visits: 1952 (UCLA, Box 1902, Folder 33) and 1960 (UCLA, Box 1902, Folder 32). While not documented with travel sketches, he also visited Japan in 1964 (UCLA, Box 133, Folder 11) and 1966-67 (UCLA, Box 893, Folder 1).

9 Richard Neutra, 'Foreword' (February 1959), in David H. Engel, Japanese Gardens for Today (Rutland, VtTokyo, 1959), pp. xi-xiii (p. xi).

10 For example, 'Japan and Total Composition of Environment', dated 10 August 1959: UCLA, Box 162, Folder 37. For more extensive analyses of Neutra's fascination with Japan, see Barbara Lamprecht, Neutra: 
Complete Works (Cologne, 2010), pp. 34-42, and Barbara Lamprecht, 'From Neutra in Japan, 1930, to His European Audiences and Southern California Work', Southern California Quarterly, 92 (2010), pp. 215-42.

11 Richard Neutra, Life and Shape (New York, 1962), p. 181.

12 Esther McCoy, Richard Neutra (New York, 1960), p. 9.

13 Lamprecht, 'From Neutra in Japan', p. 216.

14 Richard Neutra, Life and Human Habitat (Stuttgart, 1956), p. 29.

15 Hines, Richard Neutra and the Search for Modern Architecture, p. 26.

16 Hines mentions the Forest Cemetery in Luckenwalde and the private residential gardens; Ibid., p. 31. For Neutra's own account of his work in Luckenwalde, see Neutra, Life and Shape, pp. 149-52. Both Kathleen James and Regina Stephan have attributed the landscape design for Mendelsohn's Einstein Tower to Neutra; see Kathleen James, “'Organic!”: Einstein, Finlay-Freundlich, Mendelsohn, and the Einstein Tower in Potsdam', in Erich Mendelsohn, Architect 1887-1953, ed. Regina Stephan (New York, 1999), pp. 26-37 (p. 29); and Regina Stephan, "'One of the Most Loveable People and at the Same Time One of the Most Unpleasant": Mendelsohn and His Assistants in the 1920s and Early 1930s', in Erich Mendelsohn, Architect 1887-1953, ed. Regina Stephan (New York, 1999), pp. 152-59 (p. 154).

17 Hines briefly notes Neutra's personal connection with Klimt; see Hines, Richard Neutra and the Search for Modern Architecture, p. 5. While Neutra's travel sketches havenever been widely researched or published, they figured prominently in the exhibition 'Richard Neutra, Architect: Sketches \& Drawings' at the Los Angeles Public Library in 2009, curated by Thomas Hines. To my knowledge, no catalogue of this exhibition was produced, although the six podcast interviews that formed part of the audio tour (with Sarah Lorenzen, Victoria Steele, Ray Kappe, Kelly Lynch, Leo Marmol and Dion Neutra) have remained available for download on the LAPL website, at http://www.lapl. org/collections-resources/e-media/podcasts/exhibition, last accessed on 12 March 2016.

18 Neutra, Life and Shape, p. 173. For a detailed account of Neutra's impressions of the architecture of Wright's Taliesin (Spring Green), see Hines, Richard Neutra and the Search for Modern Architecture, pp. 52-55.

19 Francisco Prieto Moreno, 'Coincidencas de Neutra con las arquitecturas orientales', Arquitectura, 81 (1965), pp. 19-30; Carlos Obregón Santacilia, El maquinismo, la vida y la arquitectura (Mexico City, 1939), p. 23; Warchavchik, 'Introduction', pp. 26-34.

20 Richard Neutra, Architecture of Social Concern, (Sao Paulo, 1947); Richard Neutra, Survival Through Design (New York, 1954); Richard Neutra, Life and Human Habitat (Stuttgart, 1956); Richard Neutra, Realismo biológico. Un nuevo Renacimiento humanístico en arquitectura (Buenos Aires, 1958).

21 The subjects of these sketches, and their locations in the UCLA archive, are detailed below in notes 101, 102, 106, 107, 111, 113, 116, 129, 130 and 143 .

22 Neutra, Life and Shape, pp. 160-70.

23 Richard Neutra, Wie Baut Amerika? (Stuttgart, 1927); and Richard Neutra, Amerika: Die Stilbildung Des Neuen Bauens in Den Vereinigten Staaten (Vienna, 1930).

24 Hines, Richard Neutra and the Search for Modern Architecture, p. 28.

25 Ibid., p. 47 .

26 Neutra, Life and Shape, p. 207.

27 Ibid., p. 207.

28 Ibid., p. 212.

29 McCoy, Richard Neutra, pp. 7-8.

30 Lamprecht, 'From Neutra in Japan', p. 218.

31 McCoy, Richard Neutra, pp. 7-8.

32 Lamprecht, 'From Neutra in Japan', p. 218.

33 Letter from Richard Neutra to Rudolph Schindler, dated 4 May 1914, published in McCoy, Vienna to Los Angeles, p. 107. Neutra's letters to Schindler also indicate a desire to travel to Japan.

34 David Gebhard, Schindler (New York, 1972), pp. 27-30; Judith Sheine, R.M. Schindler (London, 2001), p. 25.

35 Letter from Richard Neutra to Rudolph Schindler, dated 1 May 1916, published in McCoy, Vienna to Los Angeles, p. 111.

36 Ibid., pp. 129-30.

37 Ibid., p. 129.

38 Lauren Weiss Bricker, 'Western Pragmatists and the Modern American House', Southern California Quarterly, 91 (2010), pp. 413-27 (p. 415).

39 The first park, Yellowstone, was established by Congress on 1 March 1872, and the National Parks Service was established by President Woodrow Wilson on 15 August 1916. See 'History', National Park Service, at http://www.nps.gov/aboutus/history.htm (accessed on 14 September 2015). 
40 Hines, Richard Neutra and the Search for Modern Architecture, p. 56.

41 UCLA, Box 1288, Folder 9.

42 UCLA, Box 1904, Folder 3 and UCLA, Box 2, Folder 71, respectively.

43 UCLA, Box 3, Folders 17, 18 and 19.

44 UCLA, Box 134, Folder 22.

45 Lamprecht, Neutra: Complete Works, p. 400.

46 Richard J. Neutra and Robert Alexander, 'El "Painted Desert \& Petrified Forest", centro turístico, en Arizona U.S.A.', in Richard J. Neutra, ed. Fernando Casinello (Madrid, 1968), without pagination.

47 Carey McWilliams, North from Mexico: The Spanish-Speaking People of the United States (New York, 1948, reprinted in 1968), pp. 35-47, cited in Matthew F. Bokovoy, The San Diego World's Fairs and Southwestern Memory, 1880-1940 (Albuquerque, 2005), p. xvi.

$48 \mathrm{Ibid}$. In the notes on p. 227, Bokovoy also cites several works on California's 'fantasy heritage' by Douglas Monroy.

49 Phoebe Kropp, California Vieja: Culture and Memory in a Modern American Place (Berkeley, 2006), pp. 1 and 5. 50 For a detailed account of Goodhue's use of the Spanish Baroque for the 1915 Panama-Pacific Exposition in San Diego, and its influence in the architecture of Southern California, see Bokovoy, The San Diego World's Fairs.

51 Cristina López Uribe, 'Reflections of the "Colonial"', in Latin American Modern Architectures: Ambiguous Territories, ed. Patricio del Real and Helen Gyger (New York, 2013), pp. 215-34 (p. 215).

52 Phoebe Kropp, review of Matthew F. Bokovoy, The San Diego World's Fairs and Southwestern Memory, 18801940, Southern California Quarterly, 88 (2007), pp. 48o-82 (p. 482).

53 Richard Neutra, Architect: Sketches \& Drawings.

54 Ibid.

55 Hines, Richard Neutra and the Search for Modern Architecture, p. 229.

56 Ibid., p. 22.

57 While working with Wright at Taliesin, Neutra served as draftsman for the 1923 Millard House in Pasadena; see Lamprecht, Neutra: Complete Works, p. 22. In 1925 he collaborated with Schindler to design the pergola and wading pool for the Barnsdall House; see Hines, Richard Neutra and the Search for Modern Architecture, p. 59.

58 Cited in Alice Friedman, Women and the Making of the Modern House: A Social and Architectural History (New York, 1998), p. 51.

59 Cited in Melanie Simo, Barnsdall Park: A New Master Plan for Frank Lloyd Wright's California Romanza (Washington, DC, 1997), p. 26.

6o Donald Leslie Johnson, On Frank Lloyd Wright's Concrete Adobe: Irving Gill, Rudolph Schindler and the American Southwest (Farnham, 2013), pp. 122-29. The reference to Navajo, Walpi and Pueblo Indian architecture occurs on p. 126. This passage of Johnson's text refers specifically to the Barnsdall House, but on page 164 he identifies the visual similarities between Wright's textile block houses, including the Millard House, and the indigenous architecture of the American Southwest: 'The only difference in external appearance between those houses, [Irving] Gill's, and the Indians' high desert buildings was the textured walls' (emphasis in original).

61 Friedman, Women and the Making of the Modern House, p. 51. Friedman also includes a helpful list of sources that confirm Wright's interest in Maya architecture and the architecture of the American Southwest.

62 Kathryn Smith, Frank Lloyd Wright, Hollyhock House and Olive Hill: Buildings and Projects for Aline Barnsdall (New York, 1992), p. 43. For a more complete analysis of Wright's study of Mayan architecture (particularly in the context of textile block houses), see Dimitri Tselos, 'Frank Lloyd Wright and World Architecture', Journal of the Society of Architectural Historians, 28 (1969), pp. 58-72; and Marjorie I. Ingle, The Mayan Revival Style: Art Deco Mayan Fantasy (Salt Lake City, 1984), pp. 13-19.

63 Judith Sheine, R. M. Schindler (London, 2001), pp. 27-28; Gebhard, Schindler, p. 30.

64 Sheine has described Schindler's design for the T.P. Martin House as a reinterpretation of Loos' Raumplan in Ibid.

65 Esther McCoy, Five California Architects (New York, 1960), p. 153.

66 Robert Sweeney and Judith Sheine, Schindler, Kings Road, and Southern California Modernism (Berkeley, 2012), p. 77 .

67 Perhaps David Gebhard exaggerated when he stated that these two projects 'could, within reason, be labelled Pueblo Revival', yet Schindler's use of local materials (e.g. stucco) and forms (e.g. canted wall panels) are indeed easily related to his study of local architecture; see Gebhard, Schindler, p. 47.

68 McCoy, Vienna to Los Angeles, p. 26. 
69 Drexler, The Architecture of Richard Neutra, p. 7.

70 Hines, Richard Neutra and the Search for Modern Architecture, p. 59; and Thomas Hines, Irving Gill and the Architecture of Reform (New York, 2000), pp. 34-38 and 242.

71 Hines, Irving Gill, p. 258.

72 Thomas Hines has stated that Loos visited Chicago at precisely the time as when Gill and Wright were working in Sullivan's studio, although Hines does not state that Loos and Gill actually met personally; see Ibid., p. 129.

73 Hines, Richard Neutra and the Search for Modern Architecture, p. 59.

74 Hines, Irving Gill, p. 260.

75 Hines, Irving Gill, pp. 77-78.

76 Ibid., p. 78.

77 Ibid., p. 70 .

78 Neutra, Amerika, pp. 76, 118-19, 121 and 124-27. Neutra also dedicated a section of the text in this book (pp. 46-50) to the theories of Wright and Gill.

79 Hines, Richard Neutra and the Search for Modern Architecture, p. 59.

80 Alson Clark, "The "Californian" Architecture of Gordon B. Kaufmann', Society of Architectural Historians Southern California Chapter Review, 3 (1982), pp. 1-8 (p. 3).

81 López Uribe, 'Reflections', p. 217.

82 Hines, Richard Neutra and the Search for Modern Architecture, p. 59.

83 Richard Neutra to Lilly Müller Niedermann ('Mütterli'), dated March 1925; published in Dione Neutra, Richard Neutra, Promise and Fulfillment, 1919-1932 (Carbondale, Ill., 1986), p. 137. This collection typically dates the letters according to month and year, but not day.

84 Hines, Richard Neutra and the Search for Modern Architecture, p. 59.

85 Clark, 'The "Californian" Architecture of Gordon B. Kaufmann', pp. 3-4.

86 Hines, Richard Neutra and the Search for Modern Architecture, pp. 59, 61 and 70-73. Hines clarifies that all of these projects were collaborations between Neutra and Schindler in just name, since the ideas generating their designs were mostly Neutra's (except for the wading pool at the Barnsdall House, which was a more truly collaborative endeavour).

87 Ibid., p. 6o. The exact date of these houses in unknown, but Hines lists it as 'circa 1927'. The original drawings for these houses are kept in UCLA, Oversize Folder 943.

88 Neutra's working drawings for the Richmond Civic Centre survive, and are kept in UCLA, Box 585 .

89 Cited in McCoy, Vienna to Los Angeles, p. 53.

90 Ibid., p. 53 .

91 Hines, Richard Neutra and the Search for Modern Architecture, p. 59.

92 Cited in Ibid.

93 UCLA, Oversize Folder 1252.

94 Richard Neutra, Architect: Sketches \& Drawings.

95 Hines described the Rajagopals addition as 'a strikingly "modern" but sympathetic addition'; see Hines, Richard Neutra and the Search for Modern Architecture, p. 141. However, Neutra's decision to treat the addition as a second-storey apartment over only half of the original house, and his addition of ribbon windows and aluminium panelling, disregard the symmetrical composition and material palette that contribute to the spirit of the original house.

96 Lamprecht, Neutra: Complete Works, p. 117.

97 On page 82 of Richard Neutra and the Search for Modern Architecture, Hines includes a reproduction of Neutra's original floor plans for the Lovell Health House, in which two spaces on the top floor are labelled 'sleeping porches'. In his autobiography, Neutra indicated that it was in the Lovell Health House that he first experimented with 'sleeping porches'; see Neutra, Life and Shape, p. 224. He was probably inspired by Schindler's use of 'sleeping porches' in the 1921 Schindler-Chase House.

98 Barbara Lamprecht, Richard Neutra, 1892-1970: Survival Through Design (Cologne-London, 2004), p. 35.

99 McCoy, Richard Neutra, p. 20.

100 Hines, Richard Neutra, Architect: Sketches \& Drawings.

101 Neutra's sketches of these buildings are in the UCLA archive. The Cathedral of San Juan (1945): UCLA, Box 3, Folder 8; Nuestra Señora del Carmen (1945): UCLA, Box 1, Folder 53; San Patricio Parish (1944; mistakenly labelled 'S. Patricia' by the archivist): UCLA; Box 3, Folder 15; the Cathedral of San Cristobal (1945): UCLA, Box 1, Folder 48; Mission San Antonio de Pala (1939): UCLA, Box 1904, Folder 8; and Mission Santa Inés (1941): UCLA, Box 2, Folders 86-87. 
102 For example, the Neutra sketch entitled 'Valenciana 1956' shows 'a view of three women wearing in costume [sic] dancing in front of a man and a woman in Comunidad Valenciana' (description supplied by the archivist); UCLA, Box 1903, Folder 14. Another sketch is entitled 'Argentina 1945, Nuns and Gauchos over the Pampas', although the archivist described it as 'View of a nun and children riding in a horse drawn carriage. A gaucho riding a horse is in the right foreground'; UCLA, Box 1, Folder 5.

103 Weiss Bricker, 'Western Pragmatists', p. 414.

104 Dion Neutra, interview by Brett Tippey (Los Angeles, 23 June 2009).

105 Richard Neutra, 'Introduction', in Irving Myers, Mexico's Modern Architecture (New York, 1952), p. 20. Seven years after publishing his introduction to Myers's book, Neutra made a similar statement about feeling 'at home' in Japan; see Neutra, 'Foreword', in Engel, Japanese Gardens for Today, p. xi.

106 The quote is the archivist's description of the sketch. Neutra's original title simply reads 'Xochimilco'; UCLA, Box 1903, Folder 6.

107 The UCLA archive keeps multiple travel sketches that document Neutra's trips to Mexico in the following years: 1937 (UCLA, Box 2, Folder 22); 1951 (UCLA, Box 1903, Folders 1-4); 1962 (UCLA, Box 2, Folder 21); and 1963-64 (UCLA, Box 133, Folder 12). Neutra also visited Mexico in 1952 to participate in the VIII Congreso Panamericano de Arquitectos, as documented in 'VIII Congreso Panamericano de arquitectos: Méjico 1952', Revista nacional de arquitectura, 127 (1952), pp. 38-39 (p. 38). It is likely that he visited many more times, although such trips are not documented in the archives.

108 UCLA, Box 2, Folders 24 and 28.

109 Richard Ingersoll, 'In the Shadows of Barragán', in Luis Barragán: The Quiet Revolution, ed. Federica Zanco (Milano, 2001), p. 218.

110 Hines, Richard Neutra and the Search for Modern Architecture, p. 189.

111 Travel sketch entitled 'Tan Yuka Pyramid, Serpent, Diego \& Frida Rivera, 1937'; UCLA, Box 1287, Folder 7.

112 Cited in Hines, Richard Neutra and the Search for Modern Architecture, p. 189.

113 Travel sketch entitled 'Una Tarde De Toros, Mexico, 1937, Dec. 12'; UCLA, Box 2, Folder 27.

114 Neutra, 'Introduction', p. 20.

115 Luis E. Carranza, Architecture as Revolution (Austin, Texas, 2010), p. 144.

116 Travel sketch entitled 'Universidad, Mexico', dated (by the archivist) 1957; UCLA, Box 1903, Folder 5.

117 William Curtis, Modern Architecture Since 1900 (London, 1996), p. 493.

118 Neutra, 'Introduction', p. 21.

119 Neutra's participation in the 1963 conference in Mexico City is documented in UCLA, Box 1419, Folder 42, which is entitled by the archivist 'International Congress of Architects 1963'. Box 133, Folder 12 (entitled 'Trip Contacts-Mexico: 1963-1964') also gives evidence of this visit. It is unknown whether or not Neutra actually visited the National Museum of Anthropology and History, but throughout his travels, such important buildings typically did not escape his notice.

120 Carlos Obregón Santacilia, México como eje de las antiguas arquitecturas de América (Mexico City, 1947), pp. 30-39.

121 Enrique Yañez, 'Forward', in Mexico's Modern Architecture, ed. Irving Myers (New York, 1952), pp. 9-14 (p. 9). Irving Myers had apprenticed with Neutra, and he and his wife maintained contact with Neutra and his wife Dione, particularly in 1951-52. A series of letters between the Myers' and the Neutras are kept in the Neutra Archive at UCLA in Box 217, Folder 10.

122 Irving Myers, Mexico's Modern Architecture (New York, 1952), p. 18.

123 Neutra, 'Introduction', p. 21.

124 'Puerto Rico', Architectural Forum (March 1945), pp. 119-31 (p. 121).

125 Ibid.

126 Ibid.

127 Richard Neutra, 'Puerto Rico - Island of Promise', Survey Graphic, 33 (June 1944), pp. 293-95 (p. 293).

128 In addition to the many projects he had constructed prior to 1944 in California, Neutra had also completed two in Texas: the 1937 Kraigher House (Brownsville) and the 1942 Avion Village Housing Project (Grand Prairie); see Hines, Richard Neutra and the Search for Modern Architecture, pp. 309-11. In 1939, Neutra also designed the unbuilt Park Living Colony for Jacksonville, Florida; see McCoy, Richard Neutra, p. 103. 129 Travel sketches, UCLA, Box 3, Folder 8 (Cathedral of San Juan); Folder 11 (cottages in Loiza); and Folder 15 (San Patricio Church).

130 Travel sketches, UCLA, Box 3, Folder 9 (El Yunque Forest); Folders 12 and 14 (beaches); and Folders 13 and 16 (tropical vegetation). 
131 'Puerto Rico', Architectural Forum, p. 121. According to this article (p. 121), the intention of the US Federal Government was that Neutra would 'turn out trainees to serve the island and its various new industries [...]. The workers thus trained would also be encouraged to emigrate to other countries in need of skilled artisans, preferably to parts of Latin America'. Most noteworthy among Neutra's collaborators on the project was German immigrant Henry Klumb (1905-84), whose work in Puerto Rico in the following decades became a prime model for Modern architecture in the tropics; see Silvia Arango, 'Henry Klumb and the University of Puerto Rico, Río Piedras Campus: The Logic of the Results', in Henry Klumb: an Architecture of Social Concern, ed. Enrique Vivoni Farage (San Juan, Puerto Rico, 2006), pp. 81-142 (p. 157).

132 Neutra, 'Puerto Rico - Island of Promise', p. 293.

133 Barbara Lamprecht has described the flexibility of these spaces in Lamprecht, Neutra: Complete Works, pp. 86 and 260 .

134 Lamprecht, Richard Neutra, 1892-1970: Survival Through Design, p. 79.

135 The editors made this statement in a foreword to the article. See also Richard Neutra, 'Observations on Latin America', Progressive Architecture, 27 (May 1946), pp. 67-72 (p. 67).

136 Ibid., p. 72.

137 Warchavchik, Introduction, p. 34.

138 Neutra, 'Observations', p. 68.

139 Ibid., p. 68.

140 Ibid., p. 72 (emphasis original).

141 Ibid., p. 70 .

142 Ibid., p. 71.

143 Neutra documented his visits through Latin America and Spain with travel sketches, which are kept, typically one per folder, in the UCLA archive: seventeen sketches in Mexico (UCLA, Box 2, Folders 20-28; Box 1287, Folders 6-7; and Box 1903, Folders 1-6); nine in Puerto Rico (UCLA, Box 3, Folders 8-16); two in Argentina (UCLA, Box 1, Folders 5-6); nine in Brazil (UCLA, Box 1, Folders 13-21); one in Panama (UCLA, Box 2, Folder 31); nineteen in Peru, including Machu Picchu, Pisac, Lake Titicaca, Arequipa, Cuzco, Lima and Juliaca (UCLA, Box 2, Folders 32-46 and Box 1287, Folders 9-12); six in Dominican Republic (UCLA, Box 1, Folders 52-57); three in Cuba (UCLA, Box 1, Folders 48-50); four in Guatemala (UCLA, Box 1902, Folders 20-23); four in Spain (UCLA, Box 1287, Folder 14; Box 1903, Folder 14; and Box 2, Folders 49-50); one in Venezuela (UCLA, Box 135, Folder 8); and four in Colombia (UCLA, Box 1902, Folders 9-12). Apparently, Neutra did not produce any sketches during his visit to Portugal in 1963-64, but his 'trip contacts' are kept in UCLA, Box 133, Folder 15. There may well be other sketches of sites in Latin America and the Iberian Peninsula scattered throughout the more than 2000 boxes in the Neutra archive.

144 UCLA, Box 143 contains several presentation panels of the unbuilt project entitled 'Red Four Blocks in Caracas, Venezuela'. A few of these drawings appear in McCoy, Richard Neutra, p. 112. Torroja also kept six large-format drawings from this project, and they can be consulted in his archive in Madrid: Archivo Torroja, CEHOPU-CEDEX ETM-410, or online at http://www.cehopu.cedex.es/etm/expt/ETM-410-001. htm (last accessed 13 March 2016).

145 UCLA, Box 1485, Folder 12, entitled (by the archivist) 'Trebol, Caracas 1957-1958'.

146 The De Schultess House, which now serves as the Swiss Embassy in Cuba, has not been the subject of much published research, although it appears in photographs in Lamprecht, Neutra: Complete Works, pp. 308-10; it is also discussed briefly in Hines, Richard Neutra and the Search for Modern Architecture, p. 273. The Gonzales-Gorrondona House (also known as the 'Quinta Gorrondona') is featured in Richard Neutra, 'Quinta Gorrondona en Caracas', Informes de la Construcción, 196 (1967), article number 161-135 (this journal does not use normal pagination but instead assigns a hyphenated catalogue number to each article). The article is reprinted under the same title in Richard J. Neutra, ed. Casinello (again without pagination).

147 Richard J. Neutra, ed. Casinello, without pagination (section entitled 'Quinta Gorrondona en Caracas'). To date, little has been published on Robles Piquer, but a brief summary of his professional career appeared in Alfonso Armada, 'Eduardo Robles Piquer' El País (Madrid), 5 October 1987.

148 'Recepción del arquitecto Richard Neutra en la Escuela Superior de Arquitectura de Madrid', Boletín de Información de la Dirección General de Arquitectura, 8 (1954), pp. 11-14 (p. 11). This article is a transcription of Neutra's lecture at the School of Architecture in Madrid (November 1954), translated from German to Spanish by José Fonseca.

149 'Esta visita ha sido para mí una satisfacción, y el cumplimiento [...] de un viejo deseo. Quisiera poder conocer mejor a España; pero la conozco muy poco, aunque ya antes de ahora, por mis lecturas y por mi actividad profesional, tenía de ella cierta información': Recepción, p. 11. 
150 'Felipe II es un viejo conocido en su mundo cultural': César Ortiz-Echagüe, 'Con Neutra por tierras de Castilla', Boletín de información de la Dirección General de Arquitectura, 8 (December 1954), pp. 22-23. Valerie Fraser has noted that, during the first half of the twentieth century, many North American architects were fascinated by the architecture of Latin America, both historical and current. As evidence, Fraser cites Wright's study of Mayan architecture, the 1943 'Brazil Builds' exhibition held at the Museum of Modern Art in New York and Neutra's 1945 goodwill tour; see Valerie Fraser, Building the New World: Studies in the Modern Architecture of Latin America 1930-1960 (London, 2000), pp. 11-15.

151 Admittedly, 'Moorish' ('morisco' in Spanish) is a difficult term; in Spain and other parts of the West it is often used pejoratively to refer to Muslims. Nonetheless, no other term so amply accommodates the vastness and diversity of the contributions Muslims had made over the course of several centuries to Spain's artistic heritage. 'Berber' is equally pejorative. 'Muslim' and 'Islamic' are overly broad and do not reflect the secularized, multi-faith culture of Medieval Spain; 'Andalusian' connotes Spain's current autonomous community of Andalusia, thereby excluding the important artistic production of Muslims in other geographic regions of Spain; 'mozárabe' is incorrect because, largely, Spain's Muslim rulers were not ethnically Arab; 'Umayyad' is too geographically diverse, since, in addition to Spain, this dynasty had ruled parts of North Africa and the Middle East; and 'Nasrid' refers to a specific dynasty that had ruled immediately prior to the Spanish Reconquista, during the final two-and-a-half centuries of the almost eight centuries of Muslim dominance in Spain.

152 The visit to the Alhambra in 1954 is recorded in a letter from Dione Neutra to Vicente Mas, dated 10 March 1969: UCLA, Box 1502, Folder 10. That de la Joya accompanied them on the 1954 trip to Granada is confirmed in a letter from Rafael de la Joya to Dione Neutra, undated (the date is likely December 1954 or January 1955, given de la Joya's New Year's wishes, 1955): UCLA, Box 1941, Folder 6.

153 Letter from Dione Neutra to Carlos de Miguel, dated 30 December 1954: UCLA, Box 1941, Folder 6.

154 Ortiz-Echagüe, 'Con Neutra en Tierras de Castilla', p. 23.

155 'esta iglesia era una de las mejores del mundo, si no la mejor entre las que él conocía': Ibid. For a more complete analysis of Neutra's visit to Spain in 1954, see Brett Tippey, 'Bienvenido Míster Neutra: Modernización y humanismo en el primer viaje de Richard J. Neutra a España, 1954', in Viajes en la transición española hacia la modernidad, ed. José Manuel Pozo and Héctor García-Diego Villarías (Pamplona, 2010), pp. 495-502.

156 Letter from Richard Neutra to Miguel Fisac, dated 30 December 1954: UCLA, Box 1941, Folder 6.

157 'primero hay que conocer a las gentes, empaparse bien de su modo de pensar y sentir y entonces intentar comprender su arquitectura': 'Recepción', p. 14.

158 Letter dated November 1955 from Construcciones y Contratas, S.A. to Richard Neutra; and letter dated 29 November 1955 from Richard Neutra to Construcciones y Contratas: both in UCLA, Box 146, Folder 6 .

159 All of these buildings had been published in Spain prior to 1956. The Corona Avenue School: Alfred Roth, 'Planificación y construcción en Estados Unidos', Revista nacional de arquitectura, 49 (1946), pp. 29-39 (p. 38); the Kaufmann Desert House: Neutra, La arquitectura como factor humano (cited in note 1); the Tremaine House: 'Dos viviendas proyectadas por R. J. Neutra', Informes de la construcción, 35 (1951), article number 161-15; the Northwestern Mutual Fire Association Building: Carlos de Miguel, 'Oficinas de una compañía de seguros, Los Ángeles', Revista nacional de arquitectura, 138 (1953), pp. 35-38; and the Eagle Rock Park Clubhouse: 'Los arquitectos opinan de arquitectura: Richard J. Neutra', Informes de la construcción, 76 (1955), article number 100-13.

160 For a more extensive discussion of the ways in which Neutra had incorporated Spanish traditional domestic values into his design for the United States Air Force Housing in Spain, see Brett Tippey, 'Genuine Invariants: The Origins of Regional Modernity in Twentieth Century Spain', Architectural History, 56 (2013), pp. 299-342 (pp. 317-20).

161 Prieto Moreno, 'Coincidencas'. For samples of his research on Spain's Moorish architectural heritage, see Francisco Prieto Moreno, 'El jardín doméstico hispanoárabe', Boletín de información de la Dirección General de Arquitectura, 17 (1950), pp. 5-8; Francisco Prieto Moreno 'Los jardines de Granada', Boletín de información de la Dirección General de Arquitectura, 23 (1952), pp. 28-30; and Francisco Prieto Moreno, "Teatro al aire libre en los jardines del Generalife', Revista Nacional de Arquitectura, 148 (1954), pp. $21-25$.

162 Prieto Moreno, 'Coincidencias', pp. 22 and 25.

163 Ibid., p. 19.

164 Ibid., p. 19. Ortega y Gasset's essay entitled 'El ideal vegetativo' was originally published in 1927 in the Spanish journal El Sol. It was reprinted in José Ortega y Gasset, Obras Completas, 9 vols (Madrid, 1964), VI, pp. 116-20. Hines opens the introduction to his book Richard Neutra and the Search for Modern Architecture with a quote (on p. 3) from Ortega y Gasset but, in an email exchange with me, Hines confirmed that he 
has no knowledge of any direct connection between Neutra and Ortega y Gasset. To date, the most comprehensive comparison of the theories of Neutra and Ortega y Gasset appears in José Vela Castillo, Richard Neutra. Un lugar para el orden. Un estudio sobre la arquitectura natural (Seville, 2003), pp. 48-49.

165 'la verdadera esencia espacial de mi trabajo esta extraída de los patrimonios arquitectónicos de España, especialmente la Alhambra de Granada'; cited in María Isabel Navarro, 'Desde el origen: la arquitectura de Fernando Higueras', Basa 24 (2001), p. 4.

166 Neutra, Life and Human Habitat, pp. 31-38.

167 Richard Neutra, 'Sun Control Devices', Progressive Architecture, 10 (1946), pp. 88-91 (p. 88).

168 Ibid.

169 Ibid.

170 Dion Neutra, interview.

171 Neutra, 'Puerto Rico - Island of Promise', p. 293.

172 Lamprecht derives Neutra's use of continuous ventilation in the Tremaine House from two sources: his 1923 project for the Diatom House, and his work in Puerto Rico; see Lamprecht, Richard Neutra, 1892-1970: Survival Through Design, p. 63.

173 Neutra, Architecture of Social Concern. Neutra's design for 'sub-soffit ventilation' can be seen on pp. 48-49, 76 and 126.

174 For a more complete discussion of Neutra's use of the patio see Brett Tippey, 'At Home in the Subtropics: Richard Neutra and the Hispanic Patio', in Subtropical Cities 2013, Braving a New World: Design Interventions for Changing Climates, ed. Anthony Abbate and Rosemary Kennedy (Washington, DC, 2013), pp. 300-08.

175 The patio of Walter Gropius's own house in Lincoln is well known. Mies van der Rohe's experimentation with the patio in single-family housing of the early to mid-1930s is fully discussed in Terrence Riley and Barry Bergdoll, Mies in Berlin (New York, 2001), which includes detailed descriptions of the following projects, all of which utilise patios: the Exhibition House and Apartment for a Bachelor (Berlin, 1931): pp. 264-67; the Gericke House (Berlin, 1932, unbuilt): pp. 268-71; the Lemke House (Berlin, 1932-33): pp. 272-75; the Hubbe House (Magdeburg, Germany, 1934-35, unbuilt): pp. 288-91; Mies's Court-House Studies (designed for various locations, 1934-35, unbuilt): pp. 292-95; the Ulrich Lange House (Krefeld, Germany, 1935, unbuilt), pp. 296-99. Also relevant to this discussion are Bergdoll's essay, 'The Nature of Mies's Space', pp. 66-105, and Riley's essay, 'From Bauhaus to Court-House', pp. 330-37.

176 Richard Neutra, 'The Patio House - A Note by Richard J. Neutra, FAIA', House and Home, vol. 10, no. 2 (August 1956), pp. 127 and 196-97 (p. 196).

177 Ibid. Neutra typically referred to the culture at Altamira by the name Monte Castillo, which denotes the complex of caves (discovered in 1879) that includes the more well-known Altamira cave. Like their counterparts in Lascaux, France (discovered in 1940), these caves are famous for their Palaeolithic paintings, in which many Modernist architects, including Neutra, were very interested. Neutra's unpublished (and undated) manuscript entitled 'Patios' also cites courtyards from 'Spanish mountain villages': UCLA, Box 161, Folder 32.

178 McCoy, Richard Neutra, p. 21. It is not clear whether or not Neutra ever visited Uxmal in person, but in 1937 he is known to have visited the ruins at nearby Chichen Itza, which he recorded in a sketch entitled 'Chich Niza Maya Pyr, 1937' (UCLA, Box 2, Folder 2).

179 Little has been written about the houses Neutra designed and built in the Zehelendorf district in Berlin. While the commission for this project was awarded to Mendelsohn's office, it does not appear in any of the following accounts of Mendelsohn's work: Erich Mendelsohn, Erich Mendelsohn: Das Gesamtschaffen Des Architekten (Berlin, 1930); Arnold Whittick, Eric Mendelsohn (London, 1940); Bruno Zevi, Erich Mendelsohn (Bologna, 1982); or Erich Mendelsohn, Architect 1887-1953, ed. Regina Stephan (New York, 1999). In a 1999 text, Zevi attributed this project to Neutra, but stated that it, and Neutra's 1927 Jardinette Apartments, 'were merely variations on Mendelsohn's designs'; see Bruno Zevi, Erich Mendelsohn: The Complete Works (Basel, 1999), p. LVII. In an endnote to her text, Kathleen James makes brief mention of the project, and states that Mendelsohn gave Neutra full credit for the design; see Kathleen James, Erich Mendelsohn and the Architecture of German Modernism (Cambridge, 1997), p. 278 (note 72). To date, Thomas Hines's brief account of this project, which he describes in terms of Neutra's collaboration with Mendelsohn, is the most thorough; see Hines, Richard Neutra and the Search for Modern Architecture, pp. 34-35.

180 See Fig. 3, above. Neutra's drawings for these houses are kept in UCLA, Oversize Folder 943.

181 The Jardinette's fully-enclosed exterior patio is evident in the plan drawing (redrawn after Neutra's original) in Lamprecht, Neutra: Complete Works, p. 90. Neutra's original drawings of this project are kept in UCLA, Box 371; Box 825, Folder 7; and Oversize Folder 1134. 
182 Neutra published a plan of the Ambrose Apartments on page 156 of his 1930 book Amerika (cited above), in which the entrance patio is labelled 'garden court'. Neutra's original drawings for this project are kept in UCLA, Oversize Folder 1143.

183 Neutra's drawings for this project (88 pieces in total) are kept in UCLA Oversize Folder 1131.

184 Neutra's design for Agricultural Workers Cooperative Housing in Riverside has not been the subject of much research, although it did appear in the exhibition 'Richard Neutra, Architect: Sketches \& Drawings'.

185 Lamprecht, Richard Neutra, 1892-1970: Survival Through Design, p. 34.

186 Obregón Santacilia, El maquinismo, p. 23.

187 Photographs of the indoor-outdoor classrooms in these schools appear in Lamprecht, Neutra: Complete Works, pp. 363-64 (National Charity League); pp. 349-50 (UCLA Elementary School); p. 395 (Richard J. Neutra School at the Lemoore Naval Air Base); and pp. 402-03 (Palos Verdes High School). For plans of the schools Neutra designed for the US Air Force bases in Spain, see UCLA, Box 146, Folder 5.

188 Dion Neutra, interview.

189 VDL Research House: Richard Neutra's Studio \& Residence, DVD produced by Cal Poly Pomona (Pomona, 2007).

190 Neutra, 'The Patio House', p. 196.

191 Dion Neutra remembers that the family occasionally took their meals in this patio (Dion Neutra, interview).

192 Neutra, 'The Patio House', p. 196 (emphasis in original).

193 Ingersoll, 'In the Shadows of Barragán', p. 219. According to Ingersoll, the exact date of this visit cannot be determined, but it most likely coincided with Barragán's 1951 visit to California to attend an architect's convention on Coronado Island, off the coast of San Diego (p. 218).

194 Neutra, 'The Patio House', p. 196.

195 Prieto Moreno, 'Coincidencias', p. 20.

196 'EI trazado de pérgolas, patios cerrados y abiertos, jardín exterior y piscina, con sus variadísimos ambientes internos, recuerda en gran manera la traza del carmen granadino, con sus acusadas influencias musulmanas': Ibid., p. 26.

197 'Los espacios de estar se centran de modo semejante a las estancias de la casa oriental, con perspectivas en varias direcciones hacia patios interiores y hacia los jardines exteriores': Ibid., p. 20.

198 Unpublished manuscript dated 30 May 1969: UCLA, Box 1502, Folder 9.

199 As described above, Neutra had used the term 'spacious porch' to define the outdoor extensions of indoor spaces that he designed for the prototype health centers in Puerto Rico; see Neutra, 'Puerto Rico - Island of Promise', p. 293. 